\title{
Derivation of Hawaiian rejuvenated magmas from deep carbonated mantle sources: A review of experimental and natural constraints
}

\author{
Anastassia Y. Borisova ${ }^{a, b, *}$, Romain Tilhac ${ }^{c}$

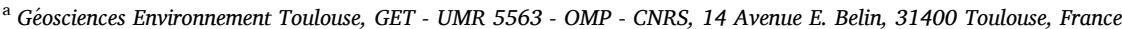 \\ ${ }^{\mathrm{b}}$ Geological Department, Lomonosov Moscow State University, MGU, Vorobievu Gori, 119991 Moscow, Russia

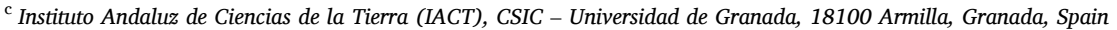

\section{A R T I C L E I N F O}

\section{Keywords:}

Review

Rejuvenated stage

Hawaiian magmatism

Carbonatite metasomatism

Mantle sources of carbonatite melts

Open-system melting

Pyroxenite

\begin{abstract}
A B S T R A C T
The role of carbon-rich or carbonatitic melts as an important metasomatizing agent in the Earth's mantle is supported by direct and indirect evidence of their involvement, ranging from the presence of erupted carbonatitic lavas to metasomatic reactions documented in minerals and melt inclusions from mantle xenoliths. Carbonatite metasomatism in hot-spot settings, and more particularly in the mantle sources of rejuvenated Hawaiian lavas, has long been suspected. However, an unequivocal geochemical tracer of carbonated mantle sources in alkaline volcanic suites is still missing. We here examine high-quality major- and trace-element compositions of $\sim 400$ primitive Hawaiian lavas $\left(\mathrm{MgO}=8.5-21 \mathrm{wt} \%, \mathrm{SiO}_{2}=37-50 \mathrm{wt} \%\right)$ and associated xenoliths, focusing on those erupted during rejuvenated stages of activity of the Hawaiian hot spot, Pacific Ocean. The rejuvenated-stage alkaline lavas are the most enriched in volatile elements among the four-stage Hawaiian lavas. Our compilation shows that these rejuvenated-stage lavas range from melilite/nephelinite to transitional basalts and are characterized by low-Si and high-Na, $-\mathrm{K}$ and -Ca contents, along with the enrichment of REE, Th and $\mathrm{Ba}$ relative to $\mathrm{K}, \mathrm{Hf}, \mathrm{Zr}$, $\mathrm{Ti}$ and $\mathrm{Nb}$. Their trace-element systematics argues against derivation from a homogeneous lherzolitic or pyroxenitic source, regardless of the involvement of residual garnet or hydrous phases. Based on a comprehensive review of natural and experimental constraints on partitioning between carbonatites and mantle minerals and numerical simulations of open-system melting, we show that it is rather consistent with carbonatite metasomatism in their source. Variations in $\mathrm{SiO}_{2}, \mathrm{CaO}$, alkali contents and trace-element proxies such as Hf/Sm also specify temporal variations in the depth of melting and/or the respective contribution of lherzolites and pyroxenites in a hybrid (probably asthenospheric) source fluxed by carbonatitic melts. We suggest that this episode took place $\leq 4.2 \mathrm{Ma}$ at temperatures and pressures in excess of $1100{ }^{\circ} \mathrm{C}$ and $2 \mathrm{GPa}$. The lowsolidus carbonatite melts were likely generated following a time lag which allowed for cooling of the plume and likely derived from an ancient $(>1 \mathrm{Ga}$ ), recycled mantle, or lower mantle, source in the Hawaiian plume, in good agreement with Sr-Nd-Hf-Os isotope systematics and other chemical and mineralogical features of Hawaiian rejuvenated lavas and xenoliths. The identification of a deep carbonated mantle source for Hawaiian rejuvenated volcanic series is also in line with noble gas and light stable isotope systematics and suggests that the interaction between carbonatite melts and peridotites/pyroxenites may be a critical process explaining the compositional variability of many oceanic island magmas.
\end{abstract}

\section{Introduction}

The presence of significant amounts of carbon in mantle plumes is well established (Trull et al., 1993; Hofmann et al., 2011; Anderson and Poland, 2017; Tucker et al., 2019). Direct and indirect evidence for carbon-rich or carbonatitic melts and fluids has been widely documented in oceanic hot-spot settings (e.g., Salters and Shimizu, 1988;
Schmidt and Weidendorfer, 2018 and references therein). Erupted carbonatite melts are, for instance, reported from the Cape Verde and Canary Islands (Allègre et al., 1971; Silva et al., 1981; Barrera et al., 1981; Gerlach et al., 1988; Hoernle et al., 2002). Metasomatic reactions between carbonatitic fluids and mantle rocks are observed in xenoliths from the Solomon (Nixon and Boyd, 1979), Canary, Kerguelen or Fernando de Noronha Islands (e.g., Kogarko et al., 1995, 2001; Schiano

\footnotetext{
* Corresponding author at: Géosciences Environnement Toulouse UMR 5563, Observatoire Midi Pyrénées, 14 Avenue E. Belin, 31400 Toulouse, France.

E-mail address: anastassia.borisova@get.omp.eu (A.Y. Borisova).
} 
et al., 1994) and Hawaii (Wirth and Rocholl, 2003). Furthermore, based on the compositions of peridotite minerals and melt inclusions, Hauri et al. (1993), Kogarko et al. (1995), Coltorti et al. (1999), Schiano et al. (1994), Mattielli et al. (1999), Hassler (1999), Grégoire et al. (2000), Kogarko et al. (2001) and Hoernle et al. (2002) inferred that ultramafic xenolith suites affected by carbonatite metasomatism are widespread in oceanic environments (e.g. Savai'i, Tubuai, Canary, Fernando de Noronha, Grande Comore and Kerguelen). Carbonatite and $\mathrm{CO}_{2}$-rich silicate melts play an important role as metasomatizing agents in the mantle lithosphere, as documented by newly formed clinopyroxene (Cpx) (Mattielli et al., 1999; Grégoire et al., 2000), apatite (Hassler, 1999), phlogopite and amphibole (Grégoire et al., 2000), and melt inclusions (Schiano et al., 1994) in metasomatized peridotites from the Kerguelen Archipelago. In fact, there is ubiquitous evidence of the involvement of carbonatites from mantle xenoliths, implying that carbonated mantle probably plays a major role in the source geochemistry of oceanic hotspot magmas.

Metasomatism by kimberlites, carbon-rich melts and carbonatites in the mantle sources of rejuvenated Hawaiian lavas has long been suspected (e.g., Salters and Zindler, 1995; Keshlav and Sen, 2003, 2004; Wirth and Rocholl, 2003; Sen et al., 2005; Frezzotti and Peccerillo, 2007; Dixon et al., 2008; Hofmann et al., 2011; Hofmann and Farnetani, 2013; Rocholl et al., 2015; Schmidt and Weidendorfer, 2018 and references therein; Rocholl et al., 2019). Alternative models for the origin of these lavas involve partial melting of garnet (Grt)-bearing lherzolites and pyroxenites leaving residual apatite, phlogopite and titanite/Fe-Ti oxides in a mixed lithosphere-plume source (e.g., Class and Goldstein, 1997; Clague and Frey, 1982; Lassiter et al., 2000; Frey et al., 2000; Sen et al., 2005; Clague et al., 2006; Garcia et al., 2016). In contrast, based on the geochemistry of the primitive Kiekie lavas and glasses from the Niihau island, Dixon et al. (2008) proposed that low-degree partial melting of the Hawaiian plume led to silicate and carbonatite metasomatism along the depleted-mantle plume margins at sub-lithospheric depths.

Compositional heterogeneities of mantle sources consequent to carbonatite metasomatism are generally inferred in intraplate magmas from $\mathrm{Hf} /$ rare earth elements (REE) and $\mathrm{Zr} / \mathrm{Hf}$ variations (e.g., Dupuy et al., 1992; Hauri et al., 1993; Hoernle et al., 2002). However, these variations can be controlled by fractional crystallization of Cpx and Grt and other authors propose that fractionation may also occur during OIB and MORB generation due to increasing bulk partitioning coefficients $\mathrm{D}_{\mathrm{Sm}}<\mathrm{D}_{\mathrm{Hf}}<\mathrm{D}_{\mathrm{Eu}}$ between mantle minerals and basaltic melts (e.g., David et al., 2000). An unequivocal geochemical tracer of carbonated mantle sources in alkaline volcanic suites is thus missing. To constrain the role of carbonatite metasomatism and/or hybrid peridotite/pyroxenite sources in the generation of the volatile-rich rejuvenated-stage Hawaiian magmas, we here present an extensive dataset of major- and traceelement compositions compiled from the literature since 1982. For that purpose, we particularly focus on high-quality analytical data on incompatible trace-elements compositions of bulk rocks (lavas), glasses and mineral samples and discuss trace-element partitioning between minerals and silicate and carbonatite melts as well as the trace-element compositions of carbonatite magmas, melts and carbonated peridotite xenoliths worldwide. These data along with the decoupled Nd-Hf isotope systematics documented in the Salt Lake Crater (SLC) mantle xenoliths (e.g., Bizimis et al., 2005, 2013 and references therein) are consistent with carbonatite metasomatism derived from a deep, potentially lower-mantle, source containing ancient recycled material $(>1 \mathrm{Ga})$ within the Hawaiian plume.

\section{Data compilation}

\subsection{Sample systematics and analytical data selected for this study}

Four volcanic stages have been distinguished in the HawaiianEmperor volcanic chain (Fig. 1a,b): (1) alkalic preshield (3\% in volume), (2) tholeiitic shield (98-95\%), (3) alkalic postshield $(<1 \%)$ and (4) alkalic rejuvenated stages $(<1 \%)$ (Clague, 1987a; Sobolev and Nikogosian, 1994). The rejuvenated-stage alkaline lavas are the most enriched in volatile elements but also the most isotopically depleted (and the most homogeneous) with highly radiogenic $\mathrm{Nd}$ and $\mathrm{Hf}$ and unradiogenic Sr (e.g., Lassiter et al., 2000; Fekiacova et al., 2007; Dixon et al., 2008; Bizimis et al., 2013; Béguelin et al., 2019; Harrison et al., 2020). To constrain the role of carbonatite fluxing and/or hybrid mantle sources in the generation of their parental magmas, we have compiled a dataset of $\sim 400$ primitive lavas and glasses with $\mathrm{SiO}_{2} \leq 50 \mathrm{wt} \%$ and $\mathrm{MgO} \geq 8.5 \mathrm{wt} \%$ (Fig. 2) from Honolulu (Oahu), Haleakala (Maui), Koloa (Kauai), the submarine Wailau landslide on Molokai, the North Arch volcanic field, lavas from West Maui and Mauna Kea as well as from volcanoes on Molokai, Niihau, Kauai, Oahu, and Kaula and other Hawaiian Islands. The volcanic activity of the selected localities is mostly related to the rejuvenated stage (Clague and Frey, 1982; Frey and Clague, 1983; Chen and Frey, 1985; Clague and Dalrymple, 1988; Maaløe et al., 1992; Chen et al., 1991; Reiners and Nelson, 1998; Frey et al., 2000; Dixon and Clague, 2001; Clague and Moore, 2002; Gaffney et al., 2004; Clague et al., 2006; Dixon et al., 2008; Cousens and Clague, 2015; Phillips et al., 2016) (Table 1). The lavas and glasses are classified as ijolites, melilite nephelinites, nepheline melilites, nepheline basanites and alkaline olivine (Ol) basalts, as well as some transitional-type basalts (Fig. 2; Table 1; Supplementary Dataset 1). These alkaline to transitional lavas were erupted after an erosion interval of $0.25-2.7 \mathrm{Ma}$ following the shield-stage volcanism (Clague, 1987b; Garcia et al., 2016 and references therein). Petrographic description of these lavas can be found elsewhere (e.g., Clague and Frey, 1982; Garcia et al., 1986; Clague and Dalrymple, 1988).

Analytical data were primarily selected based on the quality of the major- and trace-element analyses, but also aiming for sample representativity and limited or absence of secondary alteration features. Various analytical techniques performed in different laboratories were used, so we preferentially included analyses obtained using neutron activation or inductively coupled plasma mass spectrometry (ICP-MS) for $\mathrm{Hf}, \mathrm{Ta}$, Th and REE and X-ray fluorescence for $\mathrm{Zr}, \mathrm{Nb}$ and $\mathrm{Y}$. Following on previous compilations (e.g., Clague and Frey, 1982; Frey and Clague, 1983; Clague and Dalrymple, 1988; Chen et al., 1991; Frey et al., 2000), we consider that "old" data on Zr, Hf, Nb, Ba, REE, Ta and Th have an analytical precision of \pm 15 to $20 \%$, and up to $25 \%$ only (e.g., Yang et al., 2003) for the Th contents of Frey et al. (2000). In contrast, recent trace-element analyses performed by ICP-MS have $2 \sigma$ precision of $3-5 \%$ (Reiners and Nelson, 1998) and better than $0.5 \%$ for major elements. For instance, major-element compositions acquired by X-ray fluorescence (XRF) and ICP-MS trace-element analyses carried out at the Washington State University GeoAnalytical Laboratory yielded a $2 \sigma$ precision mostly $<3 \%$ based on repeated analyses of the BCR-P standard, reaching 6-7\% for incompatible lithophile elements and $<15 \%$ for Ni, Sc and Ga (Gaffney et al., 2004; Dixon et al., 2008).

\subsection{Compositional features of the Hawaiian rejuvenated-stage lavas}

The selected samples are characterized by a wide range of $\mathrm{Zr}$ (69-260 ppm), Hf (1.7-6.9 ppm), La (8.5-109 ppm), Sm (3.3-17 ppm) and Lu (0.05-0.61 ppm) abundances (Fig. 3). Where missing, Hf concentrations were calculated from $\mathrm{Zr}$ contents assuming the average $\mathrm{Zr}$ / $\mathrm{Hf}(43 \pm 10)$ of rejuvenated-stage lavas (as detailed below). This is the case for the database of Reiners and Nelson (1998) on rejuvenated-stage basalts from Kauai, which shows similar trace-element ratios and primitive mantle (PM)-normalized (Sun and McDonough, 1989) patterns compared with other rejuvenated-stage Hawaiian lavas.

Hawaiian lava series are characterized by positive correlations between $(\mathrm{Hf} / \mathrm{Sm})_{\mathrm{n}}\left[\mathrm{or}(\mathrm{Zr} / \mathrm{Sm})_{\mathrm{n}}\right]$ and $(\mathrm{Ti} / \mathrm{Eu})_{\mathrm{n}}$, particularly marked in the rejuvenated-stage lavas (Fig. 3a), and negative correlations between $(\mathrm{Hf} / \mathrm{Sm})_{\mathrm{n}}$ and $(\mathrm{La} / \mathrm{K})_{\mathrm{n}}$; the latter reach particularly high values (up to 10) in lavas from Oahu and Kauai islands (Fig. 3b). These observations 

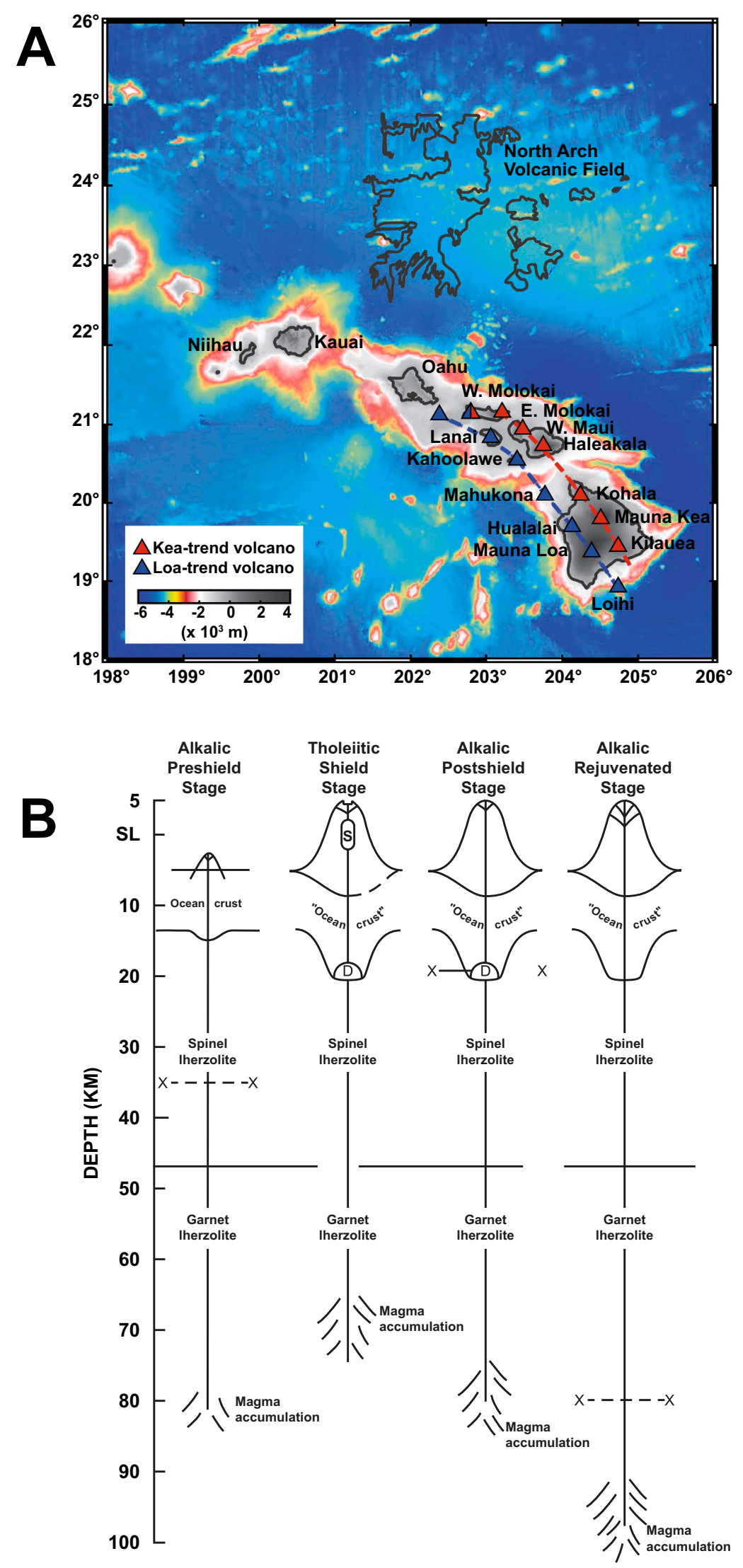

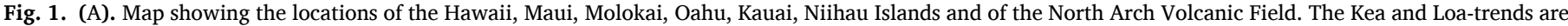

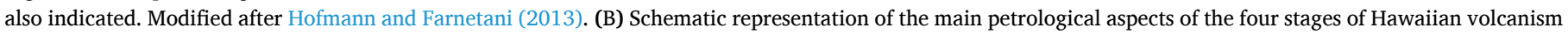
(see text for further detail). Modified after Clague (1987a, 1987b). 


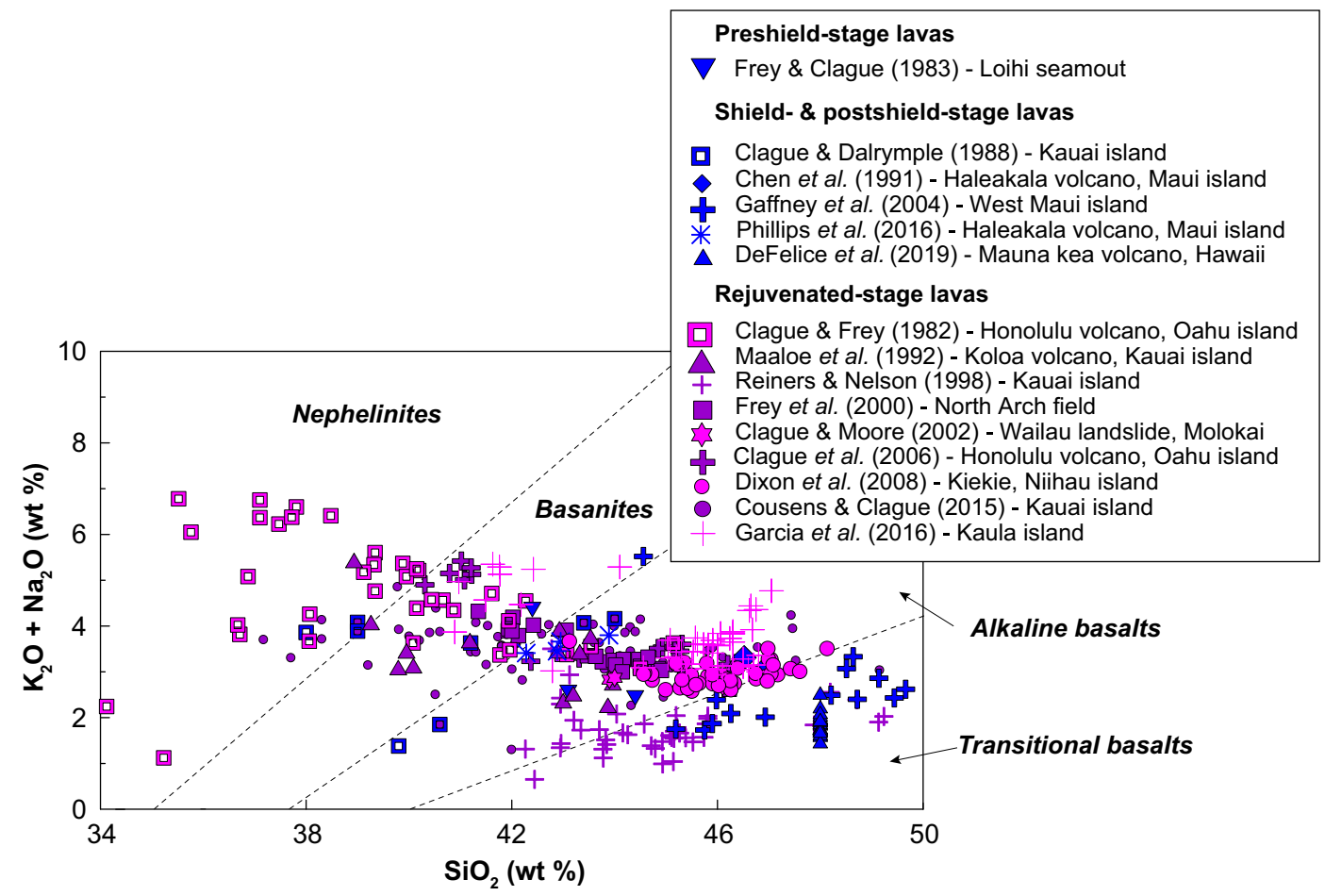

Fig. 2. $\mathrm{K}_{2} \mathrm{O}+\mathrm{Na}_{2} \mathrm{O} v s \mathrm{SiO}_{2}$ contents classification diagram for Hawaiian island lava series (nephelinites, basanites, alkaline Ol basalts and transitional basalts). The classification is after Cox et al. (1979). The compositional database includes analyses of volcanic rocks from Honolulu (Oahu), Haleakala (Maui), Koloa (Kauai), the submarine Wailau landslide on Molokai, the North Arch volcanic field, as well as lavas from West Maui and Mauna Kea, and also from volcanoes on Molokai, Niihau, Kauai and other Hawaiian Islands. For the high-Ca basalts from Mauna Kea, Hawaii island, $48 \mathrm{wt} \% \mathrm{SiO}_{2}$ is assumed. The volcanic series plotted here are related to the rejuvenated- and postshield-stages of volcanic activity (Clague and Frey, 1982; Frey and Clague, 1983; Clague and Dalrymple, 1988; Maaløe et al., 1992; Chen et al., 1991; Reiners and Nelson, 1998; Frey et al., 2000; Clague and Moore, 2002; Yang et al., 2003; Gaffney et al., 2004; Clague et al., 2006; Dixon et al., 2008; Cousens and Clague, 2015; Phillips et al., 2016; Garcia et al., 2016). The data source is given in Table 1 and summarized in Supplementary Dataset 1.

Table 1

Location, age and characteristics of the selected Hawaiian lavas and glasses.

\begin{tabular}{|c|c|c|c|c|}
\hline Volcanic stage & Location & Type of samples & Age & Reference \\
\hline $\begin{array}{l}\text { Post-erosional or } \\
\text { rejuvenated }\end{array}$ & Honolulu volcano, Oahu island & $\begin{array}{l}\text { nepheline melilitite; nephelinite; nephelinite with rare } \\
\text { melilite; basanite; alkali Ol basalt }\end{array}$ & $<0.58 \mathrm{Ma}$ & Clague and Frey, 1982 \\
\hline Preshield ${ }^{* *}$ & Loihi & basanite and alkali basalt & $5 \pm 4$ to $102 \pm 13 \mathrm{ka}$ & Frey and Clague, 1983 \\
\hline $\begin{array}{l}\text { Postshield and } \\
\text { rejuvenated }\end{array}$ & Kauai island & alkalic basalt, basanite, nephelinite, and nepheline melilitite & $\begin{array}{l}\text { between } 3.7 \text { and } 0.52 \\
\text { Ma }\end{array}$ & $\begin{array}{l}\text { Clague and } \\
\text { Dalrymple, } 1988\end{array}$ \\
\hline Postshield $* * *$ & Haleakala volcano, Maui island & alkalic basalts & $0.5-0.1 \mathrm{Ma}$ & Chen et al., 1991 \\
\hline $\begin{array}{l}\text { Post-erosional or } \\
\text { rejuvenated }\end{array}$ & Koloa volcano, Kauai island & melilitite; nephelinite; basanite; alkali Ol basalt & $\begin{array}{l}\text { a peak in the activity at } \\
1.2 \mathrm{Ma}\end{array}$ & Maaløe et al., 1992 \\
\hline Rejuvenated & Kauai island & basanites, alkali basalts & $\begin{array}{l}\text { from about } 3.5 \text { to } 0.5 \\
\text { Ma }\end{array}$ & $\begin{array}{l}\text { Reiners and Nelson, } \\
1998\end{array}$ \\
\hline Rejuvenated & North Arch volcanic field & alkalic basalt to nephelinite & $1.15-0.5 \mathrm{Ma}$ & Frey et al., 2000 \\
\hline Rejuvenated & $\begin{array}{l}\text { submarine Wailau landslide, } \\
\text { Molokai }\end{array}$ & basanites and alkaline basalts & $\begin{array}{l}\text { between } 1.5 \text { and } 1.4 \\
\text { Ma }\end{array}$ & $\begin{array}{l}\text { Clague and Moore, } \\
2002\end{array}$ \\
\hline Rejuvenated & $\begin{array}{l}\text { Hawaiian North Arch and } \\
\text { Honolulu Volcanics }\end{array}$ & melilitite; nephelinite; basanite; alkali basalt & $<0.5$ to $1.5 \mathrm{Ma}$ & Yang et al., 2003 \\
\hline $\begin{array}{l}\text { Postshield and } \\
\text { rejuvenated }\end{array}$ & West Maui & Ol basalts & $0.6-0.4 \mathrm{Ma}$ & Gaffney et al., 2004 \\
\hline Rejuvenated* & Honolulu volcano, Oahu island & alkalic basalt to nephelinite & $<0.58 \mathrm{Ma}$ & Clague et al., 2006 \\
\hline Rejuvenated & Kiekie basalt, Niihau island & basalt glasses & $3.5-0.35 \mathrm{Ma}$ & Dixon et al., 2008 \\
\hline Rejuvenated & Kaula island & nephelinites and associated xenoliths & $4.22 \pm 0.22 ? \mathrm{Ma}$ & Bizimis et al., 2013 \\
\hline Rejuvenated & Kauai island & transitional basalt to nephelinite & $2.3-0.3 \mathrm{Ma}$ & $\begin{array}{l}\text { Cousens and Clague, } \\
2015\end{array}$ \\
\hline Postshield $* * *$ & Haleakala, Maui island & basanites & $<0.15 \mathrm{Ma}$ & Phillips et al., 2016 \\
\hline Shield & Hawaii island & basalts & - & DeFelice et al., 2019 \\
\hline Rejuvenated & Kaula Island & alkalic basalt to basanite & $<1.95 \mathrm{Ma}$ & Garcia et al., 2016 \\
\hline
\end{tabular}

* Lanphere and Dalrymple (1980).

** Guillou et al. (1997).

${ }_{* * * *}$ Sherrod et al. (2003). 

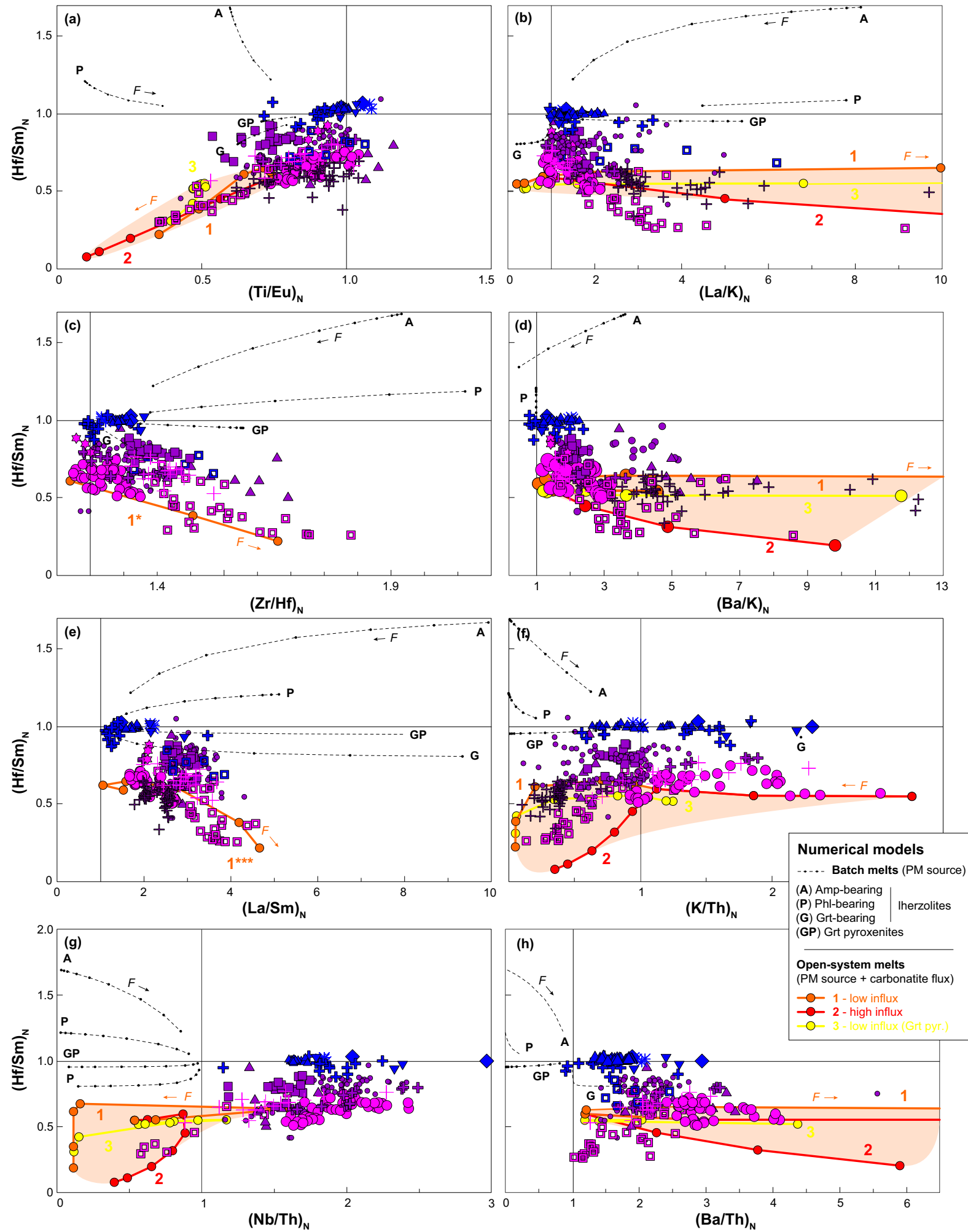

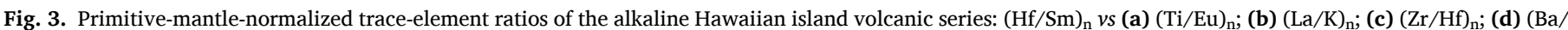

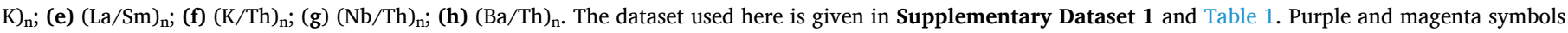

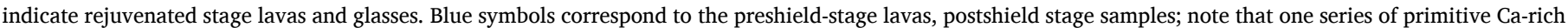

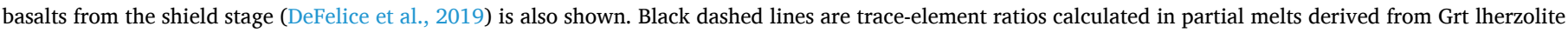



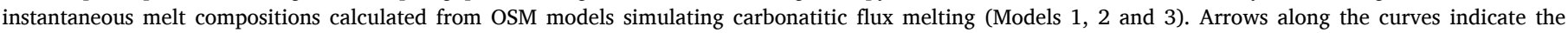

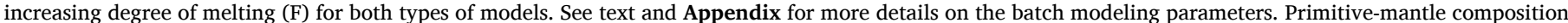

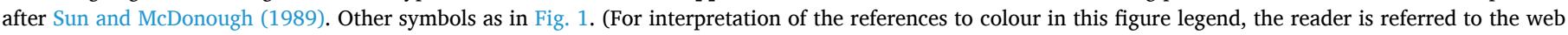
version of this article.) 
reflect coherent $\mathrm{K}, \mathrm{Zr}$, Hf and Ti depletion relative to REE compared to the PM. Negative correlations between $(\mathrm{Hf} / \mathrm{Sm})_{\mathrm{n}}$ and $(\mathrm{Zr} / \mathrm{Hf})_{\mathrm{n}}$ are also observed in some of the lavas from Honolulu volcano and Kauai (Fig. 3c). The rejuvenated-stage lava series exhibit a clear negative correlation between $(\mathrm{Hf} / \mathrm{Sm})_{\mathrm{n}}$ and $(\mathrm{La} / \mathrm{Sm})_{\mathrm{n}}$, reflecting coherent light rare earth element (LREE) enrichment and Hf depletion (Fig. 3e). Two trends of $(\mathrm{Hf} / \mathrm{Sm})_{\mathrm{n}}$ versus $(\mathrm{Nb} / \mathrm{Th})_{\mathrm{n}}$ and $(\mathrm{K} / \mathrm{Th})_{\mathrm{n}}$ reflect two types of correlations between $(\mathrm{Hf} / \mathrm{Sm})_{\mathrm{n}}\left[\mathrm{or}(\mathrm{Zr} / \mathrm{Sm})_{\mathrm{n}}\right]$ and $(\mathrm{Nb} / \mathrm{Th})_{\mathrm{n}}$ and between $(\mathrm{Hf} / \mathrm{Sm})_{\mathrm{n}}$ and $(\mathrm{K} / \mathrm{Th})_{\mathrm{n}}$ (Fig. $\left.3 \mathrm{f} \& \mathrm{~g}\right)$. In such cases, Hf depletion is accompanied by variable $\mathrm{K}$ and $\mathrm{Nb}$ depletion. Additionally, $(\mathrm{Ba} / \mathrm{Th})_{\mathrm{n}}$, and to a lesser extent $(\mathrm{Ba} / \mathrm{K})_{\mathrm{n}}$, vary widely, showing an absence of coherence between $\mathrm{K}, \mathrm{Ba}$ and $\mathrm{Th}$ behavior, but the broad negative correlation between $(\mathrm{Ba} / \mathrm{K})_{\mathrm{n}}$ and $(\mathrm{Hf} / \mathrm{Sm})_{\mathrm{n}}$ suggests that the most $\mathrm{Hf}$ depleted lavas and glasses tend to be enriched in Ba (Fig. $3 \mathrm{~d} \& \mathrm{~h}$ ).

Three geochemical groups may be distinguished among Hawaiian late-stage lavas on the primitive mantle (PM)-normalized trace-element diagrams. (1) PM-normalized trace-element patterns of the postshieldstage lavas show no distinctive anomalies for "critical" elements like $\mathrm{K}, \mathrm{Zr}$, Hf, Ti, corresponding to $(\mathrm{La} / \mathrm{K})_{\mathrm{n}},(\mathrm{Hf} / \mathrm{Sm})_{\mathrm{n}}$ and $(\mathrm{Ti} / \mathrm{Eu})_{\mathrm{n}}$ ratios close to 1 (Fig. 4). Postshield-stage lavas with moderate (La/Sm)n show different degrees of $\mathrm{Rb}$ and $\mathrm{Th}$ depletion relative to LREE. In contrast, two types of rejuvenated-stage series with low $(\mathrm{Hf} / \mathrm{Sm})_{n}<1$ may be distinguished based on characteristic anomalies in PM-normalized patterns. Both types variously exhibit $\mathrm{K}, \mathrm{Zr}, \mathrm{Hf}$ and Ti anomalies. (2) On the one hand, PM-normalized trace-element patterns of the Honolulu rejuvenated-stage lavas with low $(\mathrm{Hf} / \mathrm{Sm})_{\mathrm{n}}(<1)$ and high $(\mathrm{La} / \mathrm{Sm})_{\mathrm{n}}$ $(>3.3$ ) show strongly negative $\mathrm{Rb}, \mathrm{K}, \mathrm{Zr}, \mathrm{Hf}$ and $\mathrm{Ti}$ and positive $\mathrm{Ba}$ anomalies, and variable Th contents (Fig. 4). These anomalies are expressed in variably low $(\mathrm{La} / \mathrm{K})_{\mathrm{n}},(\mathrm{Hf} / \mathrm{Sm})_{\mathrm{n}},(\mathrm{Ti} / \mathrm{Eu})_{\mathrm{n}}$ and $(\mathrm{Ba} / \mathrm{Th})_{\mathrm{n}}$ ratios. (3) On the other hand, the Niihau rejuvenated-stage basaltic series is characterized by variable Th depletion relative to $\mathrm{Ba}$ and a weak $\mathrm{Zr}$, Hf depletions relative to REE and an absence of pronounced $\mathrm{K}$ and $\mathrm{Ti}$ depletion.

\section{Discussion}

The high MgO contents (8.5-21 wt $\%$ ) of the Hawaiian volcanic series suggest that their compositions are probably not far from that of primary melts and that the effect of fractional crystallization is negligible. Nickel contents (200-600 ppm) show broadly positive correlations with $\mathrm{MgO}$ contents in most Hawaiian lava series, reflecting some extent of fractional crystallization/accumulation. In contrast, the absence of such correlation for Sc concentrations, which are restricted to $10-30 \mathrm{ppm}$, excludes significant Cpx fractionation (Figs. A1, A2). The trace-element fractionation trends observed are thus considered below in terms of variations in source mineralogy and composition and melting processes before to envisage their geological significance.

\subsection{Source mineralogy}

\subsubsection{An anhydrous garnet lherzolite source?}

Partial melting of anhydrous Grt lherzolite/pyroxenite has been invoked in the source of Hawaiian lavas by various workers (Lassiter et al., 2000; Sobolev et al., 2005, 2007; Borghini and Fumagalli, 2020). Experimental data on trace-element partitioning (Table 2) in the presence of basaltic/basanite melts show that: (1) $\mathrm{K}_{\mathrm{d}}^{\mathrm{Hf}}$ and $\mathrm{K}_{\mathrm{d}}^{\mathrm{Sm}}$ values are similar among mantle minerals, (2) the $\mathrm{K}_{\mathrm{d}}^{\mathrm{Zr}}$ of $\mathrm{Cpx}(0.09-0.27)$ are comparable to $\mathrm{K}_{d}{ }^{\mathrm{Hf}}(0.1-0.55)$ and $\mathrm{K}_{d}{ }^{\mathrm{Sm}}(0.09-0.67)$; (3) $\mathrm{K}_{\mathrm{d}}$ vary with temperature, pressure and melt composition but remain as follows: $\mathrm{K}_{\mathrm{d}}^{\mathrm{Zr}}$ $\leq \mathrm{K}_{\mathrm{d}}^{\mathrm{Hf}} \approx \mathrm{K}_{\mathrm{d}}^{\mathrm{Sm}}$ or $\mathrm{K}_{\mathrm{d}}^{\mathrm{Hf}} \leq \mathrm{K}_{\mathrm{d}}^{\mathrm{Zr}} \approx \mathrm{K}_{\mathrm{d}}^{\mathrm{Sm}}$ in Cpx, Grt and other silicates (Table 2). This is, for instance, the case between Grt and basanitic melt (Adam and Green (2006). Corgne and Wood (2004), Corgne et al. (2012) and Bobrov et al. (2014)) also demonstrated that Hf is significantly more compatible compared to $\mathrm{Sm}$ in majoritic Grt suggesting that Hf depletion relative to $\mathrm{Sm}$ would be expected upon fractionation of majorite garnet or derivation of primary alkaline melts from such majorite Grt-bearing mantle source.

We used a batch melting model (Fig. 3, Fig. A3a-A3d) to simulate the trace-element fractionation associated with partial melting of a Grt lherzolite. The results show that $\mathrm{Hf} / \mathrm{Sm}$ and $\mathrm{Ba} / \mathrm{Th}$ in partial melts remain constant relative to the source, with a weak Ba fractionation relative to Th (Fig. A3c). Most Hawaiian rejuvenated-stage lavas exhibit such fractionation but variable $\mathrm{K}, \mathrm{Hf}, \mathrm{Zr}$ and Ti depletion (i.e. low Hf/ $\mathrm{Sm}, \mathrm{Zr} / \mathrm{Sm}, \mathrm{Ti} / \mathrm{Eu}$ and high $\mathrm{La} / \mathrm{K}, \mathrm{Zr} / \mathrm{Hf}$ relative to the $\mathrm{PM}$ ) are observed (Fig. 3a-h), which probably excludes the involvement of Grt in an anhydrous lherzolite source and instead requires additional mineral/ melt phase(s) and/or REE enrichment by metasomatism. Similarly, the observed fractionation of $\mathrm{Ba}$ from $\mathrm{Th}, \mathrm{Nb}$ and Ta could not be solely explained by the presence of majoritic Grt, owing to the similarity of its partition coefficients for these elements. The strong variations in $(\mathrm{Ba} /$ $\mathrm{Th})_{\mathrm{n}}$ at nearly constant $(\mathrm{Hf} / \mathrm{Sm})_{\mathrm{n}}$ observed, for instance, in Niihau basaltic series is clearly incompatible with the presence of majoritic Grt in their mantle source.

It is currently considered that partial melting of mantle peridotite is a dynamic process, involving differential flow of melt and residual matrix (e.g., Oliveira et al., 2020, and references therein). However, when trace elements show similar bulk distribution coefficients (e.g., Dy and $\mathrm{Yb}$ ) between mantle minerals and melts, only limited additional fractionation is expected from dynamic melting models compared to the predictions of batch melting (Eggins, 1992). Dynamic incongruent melting/ mineral dissolution can produce noticeable differences only when the partition coefficients of the produced mineral are sufficiently different from those of the reacting minerals (Zou and Reid, 2001). Dynamic melting of anhydrous lherzolitic assemblages is unable to cause any substantial trace-element fractionation in melts (e.g., $\mathrm{Hf} v s \mathrm{Sm}, \mathrm{Zr} v s \mathrm{Sm}$, La $v s \mathrm{~K}, \mathrm{~K} v s \mathrm{Ba}$ ) considering the similarity of their bulk partition coefficients (Fig. 3a-h). We conclude that the strong trace-element



Fig. 4. Primitive-mantle-normalized trace-element patterns of Hawaiian (1) postshield-stage lava samples (Ho-12 and Ho-14) with high $(\mathrm{Hf} / \mathrm{Sm})_{n}$ and low $(\mathrm{La} / \mathrm{Sm})_{\mathrm{n}}$ and (2) rejuvenated-stage lava samples (69KAL1 and 69KAL2) with low (Hf/Sm) $)_{\mathrm{n}}$ and high $(\mathrm{La} / \mathrm{Sm})_{\mathrm{n}}$; (3) rejuvenated-stage basaltic lavas (70Nii10, 69Nii-9; T318-R19; T318-R2). Data sources are Clague and Frey (1982), Chen et al. (1991) and Dixon et al. (2008). Instantaneous melt compositions calculated from OSM (Model 2) simulating carbonatitic flux melting are shown for comparison. Bulk compositional field of extrusive carbonatite magmas and carbonatite melts are from Nelson et al. (1988), Woolley et al. (1991), Beccaluva et al. (1992), and Tayoda et al. (1994). Primitive mantle composition is after Sun and McDonough (1989). 
Table 2

Partition coefficients used in melting models.

\begin{tabular}{|c|c|c|c|c|c|c|c|}
\hline & Ol & Opx & $\mathrm{Cpx}$ & Spl & Grt & Amp & $\mathrm{Phl}$ \\
\hline $\mathrm{Zr}$ & $\begin{array}{l}0.0005 \mathrm{KE}^{\mathrm{a}} 0.0025 \mathrm{R} \\
0.0003 \mathrm{FJ} \\
\underline{0.01 \mathrm{P}}\end{array}$ & $\begin{array}{l}0.014 \mathrm{KE} \\
0.027 \mathrm{R} \\
0.032 \mathrm{GR} \\
0.0099 \text { AGR } \\
\underline{0.01 \mathrm{P}}\end{array}$ & $\begin{array}{l}0.089 \mathrm{~S} \\
0.1234 \mathrm{HD} \\
0.1280 \mathrm{~J} \\
0.164 \mathrm{H} \\
0.18 \mathrm{R} \\
0.27 \mathrm{BL}\end{array}$ & $\begin{array}{l}0.001 \mathrm{R} \\
\underline{0.07 \mathrm{KE}} \\
\end{array}$ & $\begin{array}{l}0.27 \mathrm{~J} \\
0.3 \mathrm{KE} \\
2.12 \mathrm{H} \\
0.47 \mathrm{AGR}\end{array}$ & $\begin{array}{l}\frac{0.127}{0.23 \mathrm{BR}} \\
0.18-0.33 \mathrm{~A}\end{array}$ & $\begin{array}{l}\frac{0.017}{0.13 \mathrm{~A}} \\
0.23 \mathrm{BR} \\
0.008 \mathrm{GR}\end{array}$ \\
\hline Hf & $\begin{array}{l}0.0028 \mathrm{R} \\
0.001-0.004 \mathrm{D} \\
0.0008 \mathrm{FJ} \\
\underline{0.005 \mathrm{P}}\end{array}$ & $\begin{array}{l}0.025 \mathrm{R} \\
0.04 \mathrm{D} \\
0.017 \text { AGR } \\
0.06 \mathrm{GR} \\
\underline{0.01 \mathrm{P}}\end{array}$ & $\begin{array}{l}0.10-0.20 \mathrm{~T} \\
0.179 \mathrm{~S} \\
0.19 \mathrm{~F} \\
0.23 \mathrm{~J} \\
\underline{0.256 \mathrm{HD}} \\
0.29 \mathrm{H} \\
0.3 \mathrm{R} \\
0.34-0.38 \mathrm{~W} \\
0.36-0.46 \mathrm{D} \\
0.55 \mathrm{BL} \\
0.13 \mathrm{E}\end{array}$ & $\frac{0.001 \mathrm{R}}{0.003 \mathrm{E}}$ & $\begin{array}{l}0.24 \mathrm{~J} \\
0.62 \mathrm{~T} \\
1.22 \mathrm{H} \\
0.32 \mathrm{P} \\
\end{array}$ & $\frac{0.33}{0.45} \frac{\mathrm{L}}{\mathrm{BR}}$ & $\begin{array}{l}\frac{0.19}{0.45} \frac{\mathrm{L}}{\mathrm{BR}} \\
0.091 \mathrm{GR}\end{array}$ \\
\hline $\mathrm{Sm}$ & $\begin{array}{l}0.0007 \mathrm{KE} \\
0.0025 \mathrm{R} \\
\underline{0.001 \mathrm{P}}\end{array}$ & $\begin{array}{l}0.014 \mathrm{R} \\
0.02 \mathrm{KE} \\
0.011 \mathrm{AGR} \\
0.015 \mathrm{GR} \\
\underline{0.01 \mathrm{P}}\end{array}$ & $\begin{array}{l}0.086-0.22 \mathrm{~T} \\
0.201 \mathrm{~S} \\
0.281 \mathrm{~J} \\
0.291 \mathrm{HD} \\
0.33 \mathrm{H} \\
0.35 \mathrm{~F} \\
0.4 \mathrm{R} \\
0.67 \mathrm{BL} \\
0.31 \mathrm{E} \\
0.21 \mathrm{GR}\end{array}$ & $\frac{0.0006 \mathrm{KE}}{0.0006 \mathrm{R}}$ & $\begin{array}{l}0.23 \mathrm{~T} \\
0.25 \mathrm{~J} \\
0.5 \mathrm{KE} \\
0.101 \mathrm{GR} \\
\underline{0.217 \mathrm{P}}\end{array}$ & $\underline{0.66 \mathrm{BR}}$ & $\begin{array}{l}\frac{0.27}{0.66} \frac{\mathrm{G}}{\mathrm{BR}} \\
0.017 \mathrm{GR}\end{array}$ \\
\hline $\mathrm{La}$ & $\begin{array}{l}7 \mathrm{E}-06 \mathrm{KE} \\
4.5 \mathrm{E}-04 \mathrm{R} \\
0.0005 \mathrm{D} \\
\end{array}$ & $\begin{array}{l}0.0005 \mathrm{KE} \\
0.0025 \mathrm{R} \\
\underline{0.004 \mathrm{D}} \\
\end{array}$ & $\begin{array}{l}0.03 \mathrm{~S} \\
0.04-0.28 \mathrm{AG} \\
0.0536 \mathrm{HD} \\
0.06 \mathrm{R} \\
0.089 \mathrm{BL} \\
\underline{0.015 \mathrm{D}} \\
\end{array}$ & $\begin{array}{l}0.0001 \mathrm{R} \\
0.0006 \mathrm{KE} \\
\end{array}$ & $\begin{array}{l}0.001 \mathrm{KE} \\
0.0016 \mathrm{~J} \\
0.007 \mathrm{~L} \\
\end{array}$ & $\underline{0.055} \underline{\mathrm{L}}$ & $\underline{0.06} \underline{\mathrm{G}}$ \\
\hline $\begin{array}{l}\mathrm{K} \\
\mathrm{Ba}\end{array}$ & $\begin{array}{l}\frac{1 \mathrm{E}-09 \mathrm{KE}}{1 \mathrm{E}-09 \mathrm{KE}} * \\
\underline{5 \mathrm{E}-06 \mathrm{D}}\end{array}$ & $\begin{array}{l}\frac{1 \mathrm{E}-05 \mathrm{KE}}{1 \mathrm{E}-05 \mathrm{KE}} \\
\underline{6 \mathrm{E}-06 \mathrm{D}} \\
\end{array}$ & $\begin{array}{l}\frac{0.0072 \mathrm{HD}}{0.00068 \mathrm{HD}} \\
\underline{4 \mathrm{E}-04 \mathrm{D}}\end{array}$ & $\frac{0 \mathrm{KE}}{\underline{0 \mathrm{KE}}}$ & $\begin{array}{l}\frac{1 \mathrm{E}-05 \mathrm{KE}}{1 \mathrm{E}-05 \mathrm{KE}} \\
\underline{7 \mathrm{E}-05 \mathrm{D}}\end{array}$ & $\underline{0.58} \underline{\underline{0.16}} \underline{\mathrm{L}}$ & $\frac{3.67}{3.68} \frac{\mathrm{L}}{\mathrm{L}}$ \\
\hline Th & $\begin{array}{l}\overline{7 \mathrm{E}-06-1 \mathrm{E}-05} \mathrm{~B} \\
1.3 \mathrm{E}-04 \mathrm{R} \\
\underline{5 \mathrm{E}-06 \mathrm{D}} \\
\end{array}$ & $\begin{array}{l}\text { 2E-05-3E-05 B } \\
12.5 \mathrm{E}-05 \mathrm{R}\end{array}$ & $\begin{array}{l}\overline{1.5 \mathrm{E}-05 \mathrm{R}} \\
1.3 \mathrm{E}-03- \\
2.1 \mathrm{E}-03 \mathrm{~B} \\
0.0070 \mathrm{~T} \\
0.0086 \mathrm{~F} \\
0.014 \mathrm{H}\end{array}$ & $\begin{array}{l}\frac{1 \mathrm{E}-05 \mathrm{R}}{0.0014 \mathrm{H}} \\
0.0036 \mathrm{~T}\end{array}$ & $\overline{2.1 \mathrm{E}-03 \mathrm{~B}}$ & $\frac{0.0039}{0.017 \mathrm{BR}}$ & $\underline{0.0014} \underline{\mathrm{L}}$ \\
\hline $\mathrm{Nb}$ & $\frac{0.0001 \mathrm{KE}}{0.0017 \mathrm{R}}$ & $\begin{array}{l}0.0025 \mathrm{R} \\
0.003 \mathrm{KE} \\
\end{array}$ & $\begin{array}{l}0.003 \mathrm{~S} \\
0.0077 \mathrm{HD} \\
0.008 \mathrm{R} \\
0.020 \mathrm{BL}\end{array}$ & $\frac{0.01 \mathrm{KE}}{0.07 \mathrm{R}}$ & $\begin{array}{l}0.0042 \mathrm{~J} \\
\underline{0.01 \mathrm{KE}} \\
\end{array}$ & $\frac{0.159}{0.20 \mathrm{BR}}$ & $\underline{0.088 \mathrm{~L}}$ \\
\hline $\mathrm{Ti}$ & $\underline{0.015 \mathrm{KE}}$ & $\underline{0.14 \mathrm{KE}}$ & $\begin{array}{l}0.273 \mathrm{~S} \\
0.347 \mathrm{~J} \\
0.35-0.43 \mathrm{D} \\
0.384 \mathrm{HD} \\
\end{array}$ & $\underline{0.15 \mathrm{KE}}$ & $\begin{array}{l}0.28 \mathrm{~J} \\
0.6 \mathrm{KE}\end{array}$ & $\begin{array}{l}0.95 \mathrm{~A} \\
1.29 \mathrm{~L} \\
\end{array}$ & $\begin{array}{l}0.98 \mathrm{~A} \\
1.77 \mathrm{~L} \\
\end{array}$ \\
\hline $\mathrm{Eu}$ & $\begin{array}{l}9.5 \mathrm{E}-04 \mathrm{KE} \\
0.0029 \mathrm{R} \\
\underline{0.002 \mathrm{P}} \\
\end{array}$ & $\begin{array}{l}0.0185 \mathrm{R} \\
0.03 \mathrm{KE} \\
\underline{0.01 \mathrm{P}}\end{array}$ & $\begin{array}{l}0.35 \mathrm{HD} \\
0.38 \mathrm{BL} \\
\underline{0.47 \mathrm{P}} \\
0.46 \mathrm{R}\end{array}$ & $\frac{6 \mathrm{E}-04 \mathrm{KE}}{9 \mathrm{E}-04 \mathrm{R}}$ & $\begin{array}{l}1 \mathrm{KE} \\
0.4 \mathrm{P} \\
\end{array}$ & $\underline{0.88 \mathrm{IF}}$ & $\underline{0.029 \mathrm{IF}}$ \\
\hline $\begin{array}{l}\mathrm{Nd} \\
\mathrm{Ce} \\
\mathrm{Tb} \\
\mathrm{Yb}\end{array}$ & $\frac{\frac{0.00042 \mathrm{D}}{0.0005 \mathrm{D}}}{\frac{0.006 \mathrm{D}}{0.03 \mathrm{D}}}$ & $\frac{\frac{0.012 \mathrm{D}}{0.004 \mathrm{D}}}{\underline{0.0325 \mathrm{D}}}$ & $\frac{\frac{0.088 \mathrm{D}}{0.038 \mathrm{D}}}{\frac{0.165 \mathrm{D}}{0.25 \mathrm{D}}}$ & $\frac{\frac{0.0006}{0.0006}}{\underline{0.0015}^{*}}{ }^{* *}$ & $\frac{\frac{0.064 \mathrm{D}}{0.017 \mathrm{D}}}{\frac{1.6 \mathrm{D}}{\underline{4.0 \mathrm{D}}}}$ & & \\
\hline
\end{tabular}

${ }^{a}$ Partition coefficients $\left(\mathrm{K}_{\mathrm{d}}=\mathrm{C}_{\mathrm{i}}^{\text {mineral }} / \mathrm{C}_{\mathrm{i}}{ }^{\text {melt }}\right.$ ) between the main mantle minerals and basaltic or basanitic melts according to A - Adam et al. (1993); AG - Adam and

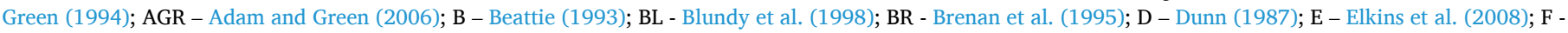

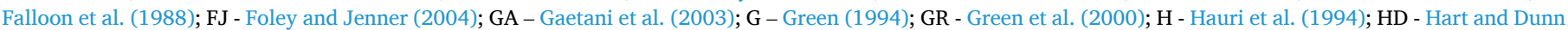

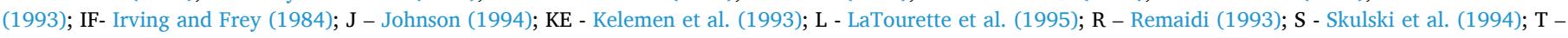

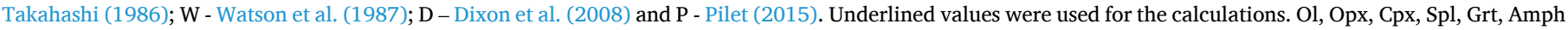
Phl denotes olivine, orthopyroxene, clinopyroxene, spinel, garnet, amphibole, phlogopite.

${ }^{*} \mathrm{~K}_{\mathrm{d}}{ }^{\mathrm{Ba}}$ values for phlogopite are considered as equal to those of $\mathrm{K}_{\mathrm{d}}{ }^{\mathrm{K}}$.

*** suggested values.

variations from PM values observed among the alkaline lavas of Hawaii rejuvenated-stage volcanism cannot be explained by simple batch nor dynamic melting models from a homogeneous, anhydrous lherzolite source, whether or not Grt (including majoritic Grt) is present.

\subsubsection{Hydrous silicate phases}

Trace-element contents of ocean-island basalts may be controlled by the presence of hydrated phases such amphibole (Amp) or phlogopite (Phl) during partial melting (e.g., Clague and Frey, 1982; Class and Goldstein, 1997; Class et al., 1998; Frey et al., 2000; Sen et al., 2005; Clague et al., 2006; Garcia et al., 2016). Both minerals have similar 
partition coefficients with basanitic melts (Green, 1994; LaTourette et al., 1995; Adam and Green, 2006). Specifically, Hf partition coefficients of Amp and $\mathrm{Phl}\left(\mathrm{K}_{\mathrm{d}}^{\mathrm{Hf}}=0.008-0.59\right)$ overlap those for $\mathrm{Sm}$ (0.017-0.66) and Zr (0.008-0.45) (Table 2; Adam et al., 1993, Green, 1994, LaTourette et al., 1995, and Adam and Green, 2006). A decrease in melting degree of an Amp- and Phl-bearing mantle source results in similar $\mathrm{Hf} / \mathrm{Sm}$ and $\mathrm{Zr} / \mathrm{Sm}$ between melt and residue, and a slightly increasing $\mathrm{Zr} / \mathrm{Hf}$ ratio in the melt (Fig. 3c, Fig. A3a). Partial melting in the presence of Amp and $\mathrm{Phl}$ are rather fingerprinted by enrichment in K, Nb, Ba and Ti relative to REE (Table 2; LaTourette et al., 1995; Brenan et al., 1995; Adam and Green, 2006).

If Amp and $\mathrm{Phl}$ were responsible for the $\mathrm{K}$ and $\mathrm{Ti}$ depletion observed in Hawaiian rejuvenated-stage lavas, they would also exhibit $\mathrm{Ba}$ and $\mathrm{Nb}$ depletion (e.g., La Tourette et al., 1995) and Th enrichment, which are not observed. If residual Amp were present, for instance, during partial melting of lherzolites, $\mathrm{Hf} / \mathrm{Sm}$ and $\mathrm{Ba} / \mathrm{K}$ ratios of the partial melts would show positive correlations, while the opposite situation is observed. Amphibole and $\mathrm{Phl}$ also have much lower La partition coefficients than those of $\mathrm{K}$ (Table 2) so that $\mathrm{Hf} / \mathrm{Sm}$ and $\mathrm{La} / \mathrm{K}$ of partial melts are expected to be positively correlated in the presence of such residual phases (Fig. 3b; Fig. A3b). Strong contrast in Amp and Phl partitioning of $\mathrm{K}$ and Ba relative to that of $\mathrm{Nb}$ and $\mathrm{Th}$ (Table 2, e.g., LaTourette et al., 1995; Green, 1994; Adam and Green, 2006) also suggests that, if these phases are present during partial melting of a homogeneous mantle source, $\mathrm{K} /$ $\mathrm{Th}$ and $\mathrm{Ba} / \mathrm{Th}$ would vary at nearly constant $\mathrm{Hf} / \mathrm{Sm}$ or $\mathrm{Zr} / \mathrm{Sm}$ (Fig. 3e,g, Fig. A3c). Weakly negative correlations between $\mathrm{Hf} / \mathrm{Sm}$ and Ti/Eu are also expected (Fig. 3a; Fig. A3d). In contrast, Hawaiian rejuvenatedstage lava series show clear negative correlations between $(\mathrm{Hf} / \mathrm{Sm})_{\mathrm{n}}$ and $(\mathrm{La} / \mathrm{K})_{\mathrm{n}}$ (Fig. $\left.3 \mathrm{~b}\right)$ and positive correlations of $(\mathrm{Hf} / \mathrm{Sm})_{\mathrm{n}}$ with $(\mathrm{K} /$ $\mathrm{Th})_{\mathrm{n}},(\mathrm{Nb} / \mathrm{Th})_{\mathrm{n}}$, and $(\mathrm{Ti} / \mathrm{Eu})_{\mathrm{n}}$ (Fig. 3a,f,g), ruling out the involvement of Amp and $\mathrm{Phl}$ in their source. A different process is therefore needed to explain the coherent $\mathrm{K}$ and high-field strength elements (HFSE) depletion and relative Th, Ba and REE enrichment.

Note that Niihau basaltic series is an exception devoid of pronounced $\mathrm{K}$ depletion relative to LREE (Fig. 4) and characterized by strong variations in $(\mathrm{Nb} / \mathrm{Th})_{\mathrm{n}},(\mathrm{Ba} / \mathrm{Th})_{\mathrm{n}}$ and $(\mathrm{K} / \mathrm{Th})_{\mathrm{n}}$ at nearly constant $(\mathrm{Hf} / \mathrm{Sm})_{\mathrm{n}}$ (Fig. 3f,g,h). The presence of hydrous phases in the mantle source of these lavas, as well as hydrous silicate fractionation, cannot be excluded, although the absence of pronounced $\mathrm{K}$ depletion relative La does not support this hypothesis.

\subsection{Carbonatite metasomatism}

The trace-element variations observed in the Hawaiian rejuvenatedstage lavas, such as the range of $\mathrm{Hf}$ depletion relative to REE, point towards significant variability of their mantle source(s). The contrasting degrees of enrichment of fluid-mobile incompatible elements (LREE, Ba and $\mathrm{Th}$ ) relative to the less mobile $\mathrm{K}, \mathrm{Hf}, \mathrm{Zr}$, Ti and $\mathrm{Nb}$ specifically points towards metasomatic enrichment in the source of Hawaiian rejuvenated-stage lavas. We concur, in this regard, with Dupuy et al. (1992) who ascribed variations of $\mathrm{Hf} / \mathrm{Sm}, \mathrm{Zr} / \mathrm{Hf}$ and $\mathrm{Zr} / \mathrm{Sm}$ in oceanisland lavas to carbonatite metasomatism of their mantle source. This interpretation also corresponds to the scenario proposed by Dixon et al. (2008), invoking coupled carbonatite-silicate metasomatism in the source of the primitive Kiekie lavas on Niihau, Hawaii. To develop a robust model compatible with all available geochemical and petrologic data on the primitive lavas (and mantle xenoliths) of the Hawaiian series, we first envisage the geochemical consequences of carbonatite metasomatism from (1) the compositions of oceanic and continental carbonatite melts/glasses and lavas, (2) experimentally determined partition coefficients between mantle minerals and carbonatite melts, (3) the compositions of mantle peridotites and pyroxenites affected by carbonatite metasomatism.

\subsubsection{Trace-element characteristics of carbonatites}

Differentiated carbonatite melts are characterized by high $\mathrm{Ba}, \mathrm{Th}, \mathrm{Sr}$,
LREE contents relative to $\mathrm{Rb}, \mathrm{K}, \mathrm{Zr}, \mathrm{Hf}, \mathrm{Ti}$ and heavy REE (HREE) (Nelson et al., 1988; Walter et al., 2008). These features may be explained by different extents of trace-element complexation with $\mathrm{CO}_{3}{ }^{2-}$ as well as carbonatite melt equilibration with majoritic Grtbearing eclogite at high pressure $(\sim 25 \mathrm{GPa}$, Corgne and Wood, 2004). Carbonatites also exhibit variable $\mathrm{Sr}, \mathrm{Ta}, \mathrm{Th}, \mathrm{Nb}$ and $\mathrm{P}$ contents, as well as significant $\mathrm{Zr} / \mathrm{Hf}$ and $\mathrm{Nb} / \mathrm{Ta}$ fractionation, potentially explained by fractional crystallization (Nelson et al., 1988; Eggler, 1989; Walter et al., 2008) and the appearance of Zr- and Nb-rich phases. In particular, $\mathrm{Zr} / \mathrm{Hf}$ range between 5 and 465,000 in continental and oceanic carbonatite series (Supplementary Data 2; Nelson et al., 1988, Gerlach et al., 1988, Woolley et al., 1991, Beccaluva et al., 1992 and Tayoda et al., 1994, Hoernle et al., 2002 and Bizimis et al., 2004) and vary widely in carbonated peridotites. For example, $\mathrm{Zr} / \mathrm{Hf}$ in the carbonated Tanzanian mantle xenoliths vary from 20 to 100 (Rudnick et al., 1993). Since the $\mathrm{Zr} / \mathrm{Hf}$ ratio in the PM is estimated to be $34-36$ (Jochum et al., 1989; Weyer et al., 2002), the effect of carbonatite metasomatism (or melting of metasomatised peridotites) in the mantle lithosphere is expected to very significant, potentially resulting in either an increase or a decrease of $\mathrm{Zr} / \mathrm{Hf}$ relative to the primitive mantle. Additionally, carbonatite melts are enriched in REE, Th and Ba relative to $\mathrm{K}, \mathrm{Zr}$, $\mathrm{Hf}$ and $\mathrm{Ti}$. Indeed, carbonatite melts with $\mathrm{CO}_{2}=17-45 \mathrm{wt} \%$ and $\mathrm{SiO}_{2}<7 \mathrm{wt} \%$ are shown to have highly variable, and systematically lower than unity, $(\mathrm{Ti} / \mathrm{Eu})_{n}=0.0004-0.27,(\mathrm{Zr} / \mathrm{Sm})_{n}=0.0006-1.1$ and $(\mathrm{Hf} / \mathrm{Sm})_{\mathrm{n}}=0.0006-0.9,(\mathrm{~K} / \mathrm{Th})_{n}=0.0003-0.9$ (Nelson et al., 1988, Gerlach et al., 1988, Woolley et al., 1991, Beccaluva et al., 1992, Tayoda et al., 1994, Hoernle et al., 2002, Bizimis et al., 2004), contrasting with high $(\mathrm{La} / \mathrm{K})_{\mathrm{n}}(2.7-4300)$ and $(\mathrm{Ba} / \mathrm{K})_{\mathrm{n}}(5-3500)$ (Fig. 5) and highly variable $(\mathrm{Ba} / \mathrm{Th})_{\mathrm{n}}(0.02-266)$. In carbonatite melts with higher $\mathrm{SiO}_{2}$ (7-22 wt\%), these ratios are much more restricted: $(\mathrm{Ti} / \mathrm{Eu})_{n}=0.2-0.3$, $(\mathrm{Zr} / \mathrm{Sm})_{n}=0.4-0.7,(\mathrm{Hf} / \mathrm{Sm})_{n}=0.6-0.9,(\mathrm{La} / \mathrm{K})_{n}=3-38$ and $(\mathrm{Ba} / \mathrm{K})_{n}=$ 4-34.

\subsubsection{Partioning between mantle minerals and carbonatite melts}

Several experimental investigations have been performed to determine the partition coefficients between mantle minerals and carbonatite melts. Green and Wallace (1988) inferred that the reaction of primary carbonatite melt with spinel (Spl) lherzolite produces an increase in large-ion lithophile elements (LILE) without any significant decrease in $\mathrm{Mg} /(\mathrm{Mg}+\mathrm{Fe})$. Brenan and Watson (1991) showed that interaction of carbonatite melt with a depleted lherzolite may markedly particularly raise the levels of LILE in Cpx. Based on experimentally determined trace-element partitioning between Cpx and carbonatite melt, Klemme et al. (1995) found that the most sensitive indicator of carbonatite metasomatism appeared to be low $\mathrm{Ti} / \mathrm{Eu}$ in the metasomatised peridotite. Over a wider range of pressure conditions, Sweeney et al. (1995) and Dasgupta et al. (2009) concluded that carbonatite metasomatism results in Ti depletion and increase in LREE/HREE, LREE/Hf and LREE/ Ti in mantle minerals. Similarly, Dalou et al. (2009) investigated trace-element partitioning between majoritic Grt and carbonatite melt at $20 \mathrm{GPa}$, demonstrating that natural magnesio- and calcio-carbonatite melts are strongly depleted in Hf relative to Sm at high-pressure; however, no data for Ti were reported by these authors.

\subsubsection{Metasomatized peridotites}

From all the available data on metasomatised peridotite xenoliths, we prefered to make use of high-quality ICP-MS data on trace element concentrations including $\mathrm{Hf}, \mathrm{Zr}$, REE, Th, Nb, Ta. Based on such data, Hauri et al. (1993) and Coltorti et al. (1999) showed that peridotite xenoliths from the islands of Savai'i, Tubuai and Grande Comore have been affected by carbonatite melts (Supplementary Dataset 2). These peridotite xenoliths show high REE abundances relative to $\mathrm{Zr}$ and $\mathrm{Ti}$. Ionov et al. (1993) performed a detailed investigation of Spitsbergen peridotite xenoliths containing primary carbonate aggregates and quenched dolomite melts. These metasomatised peridotites showed marked enrichment in LREE, Sr, Ba and depletion in $\mathrm{Zr}, \mathrm{Hf}, \mathrm{Nb}$ and $\mathrm{Ta}$. In 

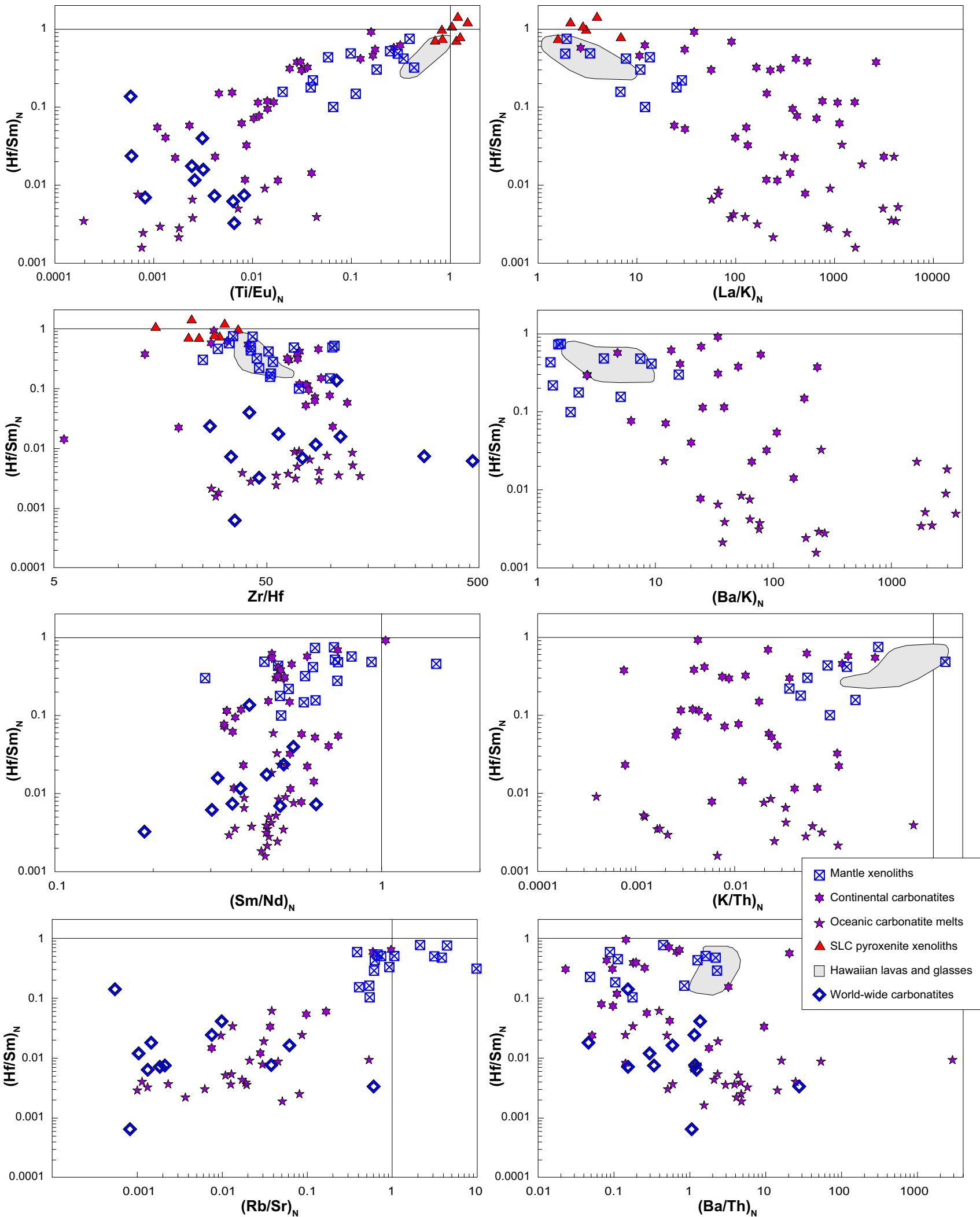



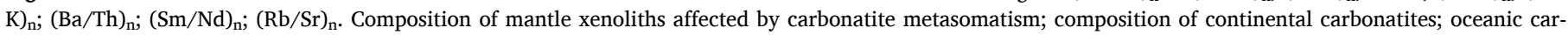

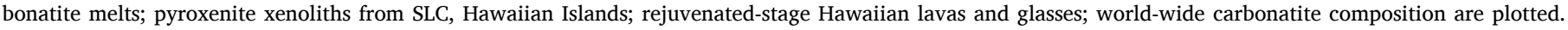

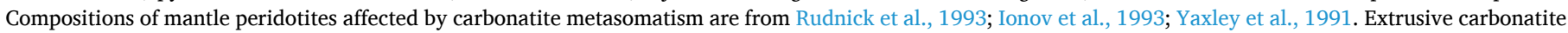

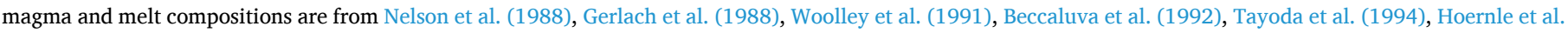

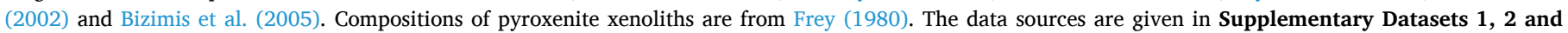
Table 1. Primitive-mantle composition after Sun and McDonough (1989). 
their investigation of the peridotite xenoliths from western Victoria, Yaxley et al. (1991) described apatite-bearing wehrlites and lherzolites, concluding that interaction between mantle peridotites and carbonatite melt results in LILE and $\mathrm{CaO}$ enrichment of the peridotites (Yaxley et al., 1991). Similar features have been described by Rudnick et al. (1993) in carbonated Tanzanian peridotite xenoliths. The main geochemical characteristics of such metasomatized xenoliths are LREE enrichment and strong Ti depletion (Fig. 5), with low (Ti/Eu) $)_{n}=0.02-0.4,(\mathrm{Hf} / \mathrm{Sm})_{n}$ $=0.1-0.7,(\mathrm{Zr} / \mathrm{Sm})_{n}=0.12-1.5,(\mathrm{~K} / \mathrm{Th})_{n}=0.04-1.3,(\mathrm{Nb} / \mathrm{Th})_{n}=$ $0.27-1.0$ and high $(\mathrm{La} / \mathrm{K})_{n}=1.8-54$ and $(\mathrm{Ba} / \mathrm{K})_{n}=1.2-15.8$ and variable $(\mathrm{Ba} / \mathrm{Th})_{n}=0.05-2.3$ (Ionov et al., 1993; Rudnick et al., 1993; Yaxley et al., 1991), also reflecting variable $\mathrm{K}, \mathrm{Hf}, \mathrm{Zr}$ and $\mathrm{Nb}$ depletion relative to adjacent $\mathrm{REE}, \mathrm{Th}$ and $\mathrm{Ba}$. $\mathrm{Rb} / \mathrm{Sr}$ and $\mathrm{Sm} / \mathrm{Nd}$ ratios also decrease during metasomatic processes involving carbonatitic fluids/ melts (Fig. 5), which results in time in reduced radiogenic ingrowth of $\mathrm{Sr}$ and $\mathrm{Nd}$ isotope ratios in the mantle source (Meen et al., 1989).

\subsection{Carbonated sources in the Hawaiian mantle}

As discussed above, carbonatite metasomatism is fingerprinted by high $\mathrm{La} / \mathrm{K}, \mathrm{Ba} / \mathrm{K}$ and low $\mathrm{Hf} / \mathrm{Sm}, \mathrm{Zr} / \mathrm{Sm}$, and Ti/Eu. These signatures are not only consistent with the compositional variability of Hawaiian rejuvenated volcanic series studied, but they also only weakly depend on the degree of melting of the peridotite or pyroxenite protolith. We argue below that the primitive lavas erupted during Hawaiian rejuvenatedstage volcanism were derived from a heterogeneous mantle variously affected by carbonatitic metasomatism.

\subsubsection{Numerical modeling}

We performed numerical modeling to simulate the impact of carbonatite melt metasomatism on the source of the rejuvenated-stage lavas. We here focus exclusively on trace-element ratios because consistently simulating major-element compositions in such a complex (i.e. polybaric, open-system heterogeneous source) scenario is not only challenging (e.g. Oliveira et al., 2020), but it would also require making assumptions that are beyond the scope of this work. Similarly, radiogenic-isotope compositions are not considered here but discussed qualitatively in a separate section; they have been addressed in more detail by Béguelin et al. (2019) and Harrison et al. (2020).

For the purpose of this discussion, different modeling approaches were envisageable. The simplest one consisted in mixing models where carbonatitic component is added to a source then used to generate lavas via batch/fractionational melting formulations. In contrast, we formulated the hypothesis that the carbonatitic metasomatism was coeval with and related to the partial melting and used a flux melting model. This approach is fairly similar from a trace-element perspective to combined mixing/melting models but it provides a better fit to several key traceelement proxies (as demonstrated below), supporting the idea of flux melting. The model used is the open-system melting (OSM-4) of Ozawa (2001), which consists in an analytical expression of the massconservation equations of 1D steady-state melting (e.g. Iwamori, 1994) where melting degree $(F)$ is related to the influx rate $(\beta)$. The system first operates as batch melting (Shaw, 1970) until a critical porosity $\left(\alpha_{c}\right)$ is reached, from which point the system is opened to fluxing, maintaining a constant melt separation rate $(\gamma)$. We used a PM source (Sun and McDonough, 1989), which might not be ideal from an isotopic perspective (e.g. Yang et al., 2003) but is perfectly appropriate as far as trace-element ratios are concerned. The fluxing agent is a carbonatite melt whose composition was taken as that of representative sample 82LB35 from Hoernle et al. (2002). Three different scenarios were tested, assuming a Grt lherzolite source mineralogy with low influx rate ( $\beta=0.01$; Model 1$)$, the same source with a higher influx rate $(\beta=1$; Model 2) and a Grt pyroxenite source (Model 3) with the same influx rate as in Model 1. Other model inputs and parameters and corresponding assumptions are detailed in Supplementary Models.

The results show that the trace-element compositions of the
Hawaiian rejuvenated-stage lavas are particularly comparable to the instantaneous melts derived from the carbonated lherzolite and pyroxenite sources (Models 2 and 3). Variable K, Hf, Zr, Ti depletions relative to the REE, are well accounted for by high carbonatite melt fluxing (Fig. 3a-h). Model 2 indeed reproduces the variations in $\mathrm{K} / \mathrm{Th}, \mathrm{Nb} / \mathrm{Th}$ and $\mathrm{Ba} / \mathrm{Th}$ observed in most rejuvenated-stage lavas. Variations in $\mathrm{La} / \mathrm{K}$ and $\mathrm{Ti} / \mathrm{Eu} v s \mathrm{Hf} / \mathrm{Sm}$ are also well reproduced by the high-flux model but they are also compatible with the results of low-flux Models 1 and 3. We note, however, that the involvement of a $\mathrm{Zr}$-rich phase is required to reproduce the $\mathrm{Zr}$-Hf fractionation observed (as illustrated by Model 1*; Fig. 3c), whereas the observed $(\mathrm{La} / \mathrm{Sm})_{\mathrm{n}} v s(\mathrm{Hf} / \mathrm{Sm})_{\mathrm{n}}$ is best reproduced by using a slightly lower La content in the fluxing agent (Model $1 * * *$ ) (Fig. 3e). The modelled $(\mathrm{Nb} / \mathrm{Th})_{\mathrm{n}}$ are also sensitive to the critical porosity $\left(\alpha_{c}\right)$ used (i.e. the melting degree from which melt is efficiently extracted) as illustrated by Model $1 * *$ (Fig. $3 g$ ).

\subsubsection{Petrological constraints}

Experimental studies show that carbonatite melts can occur within the mantle lithosphere but may also be stable in the deeper asthenospheric mantle. The experimental work of Green and Wallace (1988) defines a distinctive window in the oceanic or young continental lithosphere's geotherm, where sodic-dolomitic carbonatite melts derived from fertile lherzolites may cause mantle metasomatism at $930-1080{ }^{\circ} \mathrm{C}$ and pressures lower than $3.1 \mathrm{GPa}$. Falloon and Green (1989) and Baker and Wyllie (1992) concluded that at pressures $>2.1-2.2 \mathrm{GPa}$, nearsolidus melts derived from peridotite $+\mathrm{CO}_{2} \pm \mathrm{H}_{2} \mathrm{O}$ below $1050{ }^{\circ} \mathrm{C}$ are dolomitic (Mg-rich carbonatite) melts. Dalton and Wood (1993) experimentally determined that near-solidus melts derived from depleted natural lherzolite at $>2.5 \mathrm{GPa}$ are carbonatites with low alkali contents similar to natural magnesio-carbonatites. Sweeney (1994) demonstrated that dolomitic melts can be in equilibrium with a peridotitic mantle at 2.0-5.0 GPa and $950-1200{ }^{\circ} \mathrm{C}$. If melt segregation and aggregation operate under such conditions, these melts may move rapidly to the surface yielding primary sodic-dolomitic carbonatite magmas or fractionated natrocarbonatite derivatives (Green and Wallace, 1988; Sweeney, 1994). However, if the carbonatite melts infiltrate a lherzolite at $<2.0 \mathrm{GPa}$ and $950-1050{ }^{\circ} \mathrm{C}$, decarbonation reactions will take place and release $\mathrm{CO}_{2}$ (Green and Wallace, 1988; Harmer and Gittins, 1998). Experimental studies and data compilations also show that eclogitederived, calcic carbonatite melts may be stable above $2 \mathrm{GPa}$ in the asthenosphere (Hammouda, 2003; Thomson et al., 2016).

Hawaiian mantle xenoliths also provide evidence for the influence of carbonatite metasomatism on the oceanic mantle. For instance, mantle minerals from anhydrous Spl lherzolites of SLC, Honolulu, Hawaii contain inclusions of a dense supercritical $\mathrm{CO}_{2}$ fluid phase $\left(1.16 \mathrm{~g} / \mathrm{cm}^{3}\right.$; De Vivo et al., 1988) and LREE-enriched Cpx (Salters and Zindler, 1995). Pyroxenite xenoliths from the SLC also consist of newly formed LREEenriched containing superdense $\mathrm{CO}_{2}\left(1.21 \mathrm{~g} / \mathrm{cm}^{3}\right)$ and apatite (Frezzotti et al., 1992; Sen et al., 1993). The estimated pressures of fluidinclusion entrapment in the SLC peridotite minerals are lower than 2.0 GPa (Frezzotti et al., 1992). At these pressures, carbonatite metasomatism results in LILE and P enrichment and conversion of Spl lherzolite to apatite-bearing wehrlite containing $\mathrm{Ol}$ and diopside (Green and Wallace, 1988). Clinopyroxene- and Grt-bearing peridotites in equilibrium with carbonatite melts would have low $(\mathrm{Hf} / \mathrm{Sm})_{\mathrm{n}},(\mathrm{Zr} / \mathrm{Sm})_{\mathrm{n}}$ and $(\mathrm{Ti} / \mathrm{Eu})_{\mathrm{n}}$, combined with high LREE/HREE ratios (Dasgupta et al., 2009). As pointed out by Salters and Zindler (1995), the low Hf/Sm and $\mathrm{Ti} / \mathrm{Eu}$ in Cpx of the anhydrous Spl lherzolites and low $(\mathrm{Hf} / \mathrm{Sm})_{\mathrm{n}},(\mathrm{Zr} /$ $\mathrm{Sm})_{\mathrm{n}}$ and $(\mathrm{Ti} / \mathrm{Eu})_{\mathrm{n}}$ (down to $0.71,0.43$ and 0.7 , respectively) measured in type-I and -II pyroxenites from SLC (Frey, 1980) are consistent with such reaction involving carbonatite melts. In fact, there is also clear evidence for incongruent dissolution of orthopyroxene during carbonation reactions in the SLC xenoliths (Rocholl et al., 2019).

To account for the metasomatism documented in Hawaiian mantle xenoliths, we argue that low-degree (carbonatitic) melts with a $\mathrm{CO}_{2}>$ $40 \mathrm{wt} \%$ and low $\mathrm{H}_{2} \mathrm{O}$ content $(1-2 \mathrm{wt} \%)$ are far more effective as 
metasomatizing agents (Green and Wallace, 1988) than the silicate melts involved in the coupled silicate-carbonatite metasomatism model proposed by Dixon et al. (2008). Despite some evidence of pargasite megacrysts equilibrated with a carbonatitic melt (e.g., Harmer and Gittins, 1998), high $\mathrm{CO}_{2}$ and low $\mathrm{H}_{2} \mathrm{O}$ activity during the metasomatism would result in partial dehydration reactions and the dissolution of hydrous minerals (e.g., Ashley et al., 2020). This leads us to suggest that the Amp-bearing or Phl-bearing veins relate to more recent hydrous silicate metasomatism in the Hawaiian mantle. This conclusion is in accordance with Keshav et al. (2007), who considered that Phl from the SLC xenoliths are not related to the formation of the host xenoliths. The water contents in anhydrous minerals of the SLC xenoliths (although relatively high) are also consistent with $\mathrm{CO}_{2}$-rich nephelinite melts adding limited amounts of water to plume mantle (Peslier and Bizimis, 2015).

\subsubsection{Temporal evolution: Pyroxenite- vs peridotite-dominated source}

Isotopic investigations of Hawaiian primitive alkaline lavas suggest that they derived from a mixed lherzolite/pyroxenite (e.g., Lassiter et al., 2000) or predominantly pyroxenitic source (Garcia et al., 2016). Such pyroxenite veins may have formed due to high-temperature crystallization of plume-derived primitive (Mg-rich) basaltic melts at pressures of $\sim 1.0 \mathrm{GPa}$ and temperature of $\sim 1300{ }^{\circ} \mathrm{C}$ (e.g., Borisova et al., 2017). To highlight potential changes in the source of the rejuvenated melts, we show in Fig. $6 \mathrm{a}-\mathrm{c}$ positive correlations of $(\mathrm{Hf} / \mathrm{Sm})_{\mathrm{n}}$ with $\mathrm{SiO}_{2}$ and negative correlations with alkalinity $\left(\mathrm{K}_{2} \mathrm{O}+\mathrm{Na}_{2} \mathrm{O}\right)$, and $\mathrm{CaO}$ in the Hawaiian volcanics. According to Lassiter et al. (2000) and Garcia and Presti (1987), melting of pyroxenite veins yield high- $\mathrm{SiO}_{2}$ (42-47 wt\%), $\mathrm{Al}_{2} \mathrm{O}_{3}$ (10-14 wt $\left.\%\right)$ and low-CaO (10-12 wt \%) melts, equivalent to the Hawaiian transitional basalts (Fig. 6). Despite the absence of experimental data on the partial melting of carbonated pyroxenites (as emphasized by Lambart et al., 2016), we speculate that this process could be involved in the petrogenesis of the high- $(\mathrm{Hf} / \mathrm{Sm})_{\mathrm{n}}$ lavas in Hawaii, which exhibit such major-element compositions. Most of the preshield and postshield high-SiO${ }_{2}$ melts with low alkalinity, $(\mathrm{La} / \mathrm{Sm})_{\mathrm{n}}$ and $\mathrm{CaO}$ contents are indeed consistent with the higher degrees of melting of mafic pyroxenite veins (Reiners and Nelson, 1998; Lassiter et al., 2000). Higher temperatures along with the lower solidi and greater melt productivity of pyroxenites (e.g., Hirschmann and Stolper, 1996; Yang et al., 1998a, 1998b; Lambart et al., 2016) could have contributed to high productivity observed in Hawaiian preshield-, shield- and postshield-stage volcanism (Clague, 1987a, 1987b).

In contrast, under relatively low-temperature conditions, carbonatite melt addition to a deep asthenospheric lherzolite source results in the generation of $\mathrm{SiO}_{2}$-poor melts (Hirose, 1997; Dasgupta et al., 2004), suggesting that most rejuvenated-stage lavas may be derived from variable degrees of carbonated flux melting of a mixed lherzolite/pyroxenite source. Furthermore, the reaction between carbonatite melts and $\mathrm{Spl}$ lherzolite is known to produce an increase in $\mathrm{Ca} / \mathrm{Al}$ and $\mathrm{Na} / \mathrm{Ca}$, along with an enrichment in LILE and REE in the carbonated lherzolite (Green and Wallace, 1988). Decreasing degrees of partial melting of a deeper mantle source also result in higher alkalinity and LREE enrichment in the melts (Fig. 3). Low $\mathrm{Hf} / \mathrm{Sm}$ and high $\mathrm{K}_{2} \mathrm{O}+\mathrm{Na}_{2} \mathrm{O}$ is consistent with the idea of flux melting, where stronger carbonatitic fluxing may have promoted deeper melting. Therefore, the higher $\mathrm{CaO}$ contents, (La/ $\mathrm{Sm})_{\mathrm{n}}$ ratios and higher alkalinity of the $\mathrm{SiO}_{2}$-poor melts characteristic of the rejuvenated-stage series may be explained by increasing carbonated metasomatism of a deeper (but still hybrid) source. We conclude that the LREE enrichment and relative Hf depletion observed in rejuvenatedstage Hawaiian series is due to the combined effect of variations in the depth of partial melting and fluxing (Figs. 3e, 4, 6). On the one hand, deep carbonated Grt lherzolites were the source of $\mathrm{SiO}_{2}$-poor $(<42 \mathrm{wt}$ $\%$ ), CaO-rich melts with high $\mathrm{La} / \mathrm{Sm}$ and low $\mathrm{Hf} / \mathrm{Sm}$ observed in most rejuvenated alkaline lavas of Honolulu, Koloa and other volcanoes of the Hawaiian Islands. On the other hand, shallow carbonated lherzolites/ pyroxenites may be the source of $\mathrm{SiO}_{2}$-richer (CaO-poor, low-La/Sm)
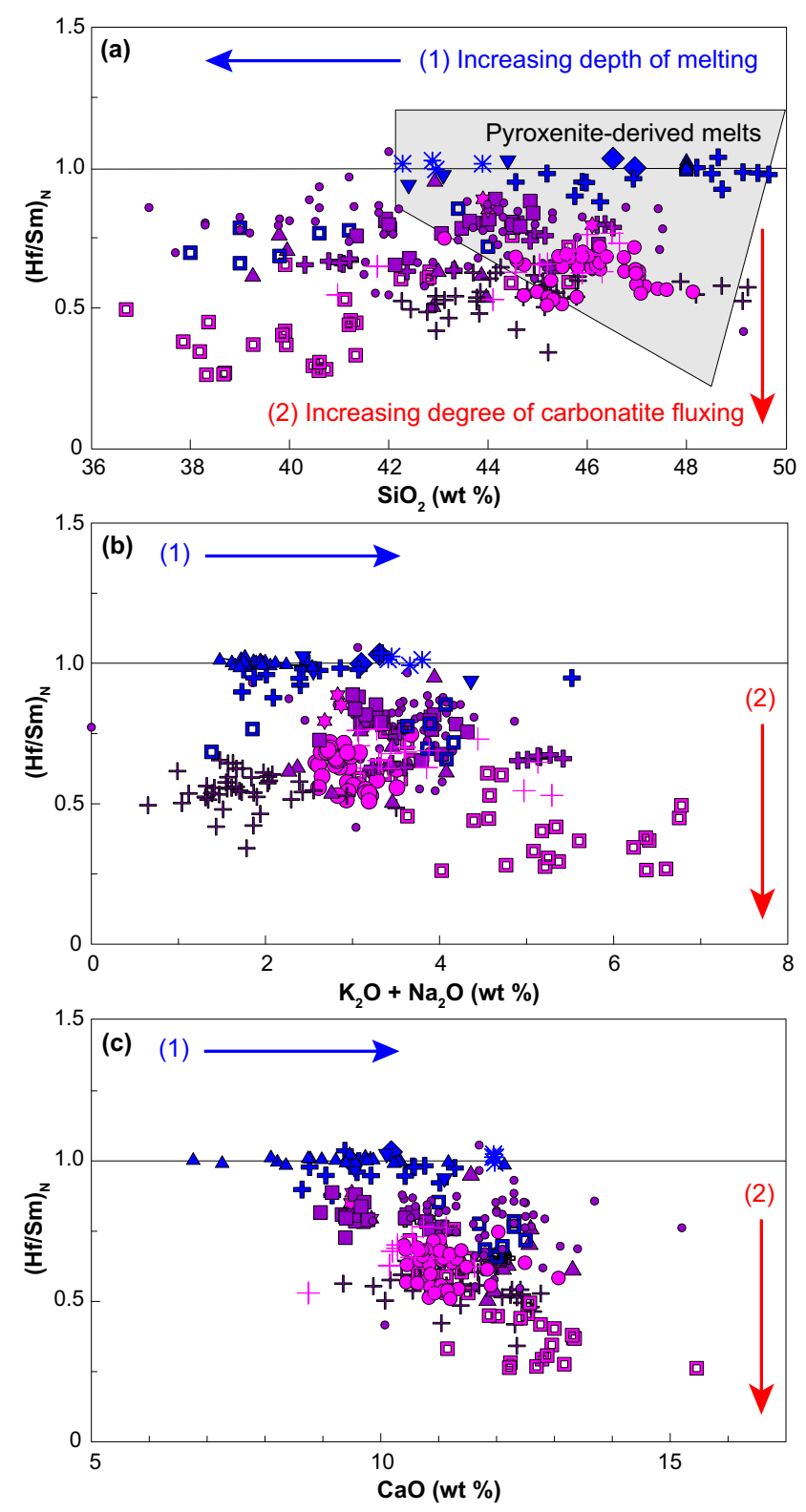

Fig. 6. (a) (Hf/Sm) $)_{\mathrm{n}} v s \mathrm{SiO}_{2(\mathrm{wt}} \%$; (b) $(\mathrm{Hf} / \mathrm{Sm})_{\mathrm{n}} v s \mathrm{~K}_{2} \mathrm{O}+\mathrm{Na}_{2} \mathrm{O}$ (wt \%) (c) (Hf/ $\mathrm{Sm})_{\mathrm{n}}$ vs $\mathrm{CaO}(\mathrm{wt} \%$ ) in the compiled Hawaiian lava series (Supplementary Dataset 1). The potential effect of changes in the depth of melting and the extent of carbonatite metatomatism are shown by the arrows, among other controlling factors discussed in the text. The grey-shadded field indicates likely compositions of melts derived from pyroxenite veins in the Hawaiian mantle. Other symbols as in Fig. 2. Primitive-mantle composition after Sun and McDonough (1989).

basaltic melts (Fig. 6). Different degrees of carbonatite flux melting would also provide a simple explanation for the double trends observed in Fig. 3h and the isotopic similarity of Niihau and Oahu lava series (NOK group; Béguelin et al., 2019) without requiring the involvement of silicate and carbonatitic metasomatic agents as suggested by Dixon et al. (2008).

\subsection{Deep carbonated sources in the Hawaiian plume}

We consider that Hawaiian rejuvenated-stage lava series are derived from a deep source, mainly asthenospheric, in a region where the lithosphere has a maximal thickness of 75-90 km (e.g., Gurriet, 1987; Liu 
and Chase, 1991; Lassiter et al., 2000; Schmidt and Weidendorfer, 2018). The $\leq 4.2-\mathrm{Ma}$, rejuvenated-stage lavas are characterized by depleted radiogenic isotopes (e.g., lower ${ }^{87} \mathrm{Sr} /{ }^{86} \mathrm{Sr}$, higher ${ }^{143} \mathrm{Nd} /{ }^{144} \mathrm{Nd}$ and ${ }^{176} \mathrm{Hf} /{ }^{177} \mathrm{Hf}$ ) compared to shield-stage basalts (Stille et al., 1983; Frey et al., 2000; Frey et al., 2005; Fekiacova et al., 2007; Garcia et al., 2010; Béguelin et al., 2019; Harrison et al., 2020). Available Sr-Hf-NdOs isotope systematics of the rejuvenated-stage lavas and associated mantle xenoliths suggest the presence in the Hawaiian plume of a depleted component that is distinct from the Pacific MORB asthenospheric source (Bizimis et al., 2005; Bizimis et al., 2007; Bizimis et al., 2013; Harrison et al., 2020). Additionally, Béguelin et al. (2019) argued for multiple depleted components in the source of the rejuvenated lavas assuming a unique shield-like (Kalihi) plume component in their mixing models while other alternatives are certainly possible in Hf-Nd isotopic space. Our results are not incompatible with these inferences and we envisage that the most isotopically depleted component may reflect the derivation of the carbonatite melts from an old $(>1 \mathrm{Ga})$ and depleted material with highly radiogenic Hf-isotope compositions, possibly representing long-lived recycled lithospheric mantle within the Hawaiian plume. In such case, provided that they affect the overlying asthenospheric mantle (e.g., Thomson et al., 2016), the carbonatite melts would be highly mobile (due to low viscocity and ability to wet silicate minerals) and may percolate from the mantle transition zone to the base of the upper mantle at about $2 \mathrm{GPa}$ pressure (e.g., Hofmann et al., 2011).

Alternatively, high carbon solubility in the core (e.g., Dasgupta and Walke, 2008) could result in production of the carbonatite melts in the lower mantle (Dobretsov and Shatskiy, 2012) following core-mantle interactions (e.g., Rizo et al., 2019), which could be envisaged as the deepest plume source of the rejuvenated lavas. Lower mantle source which is likely intrinsic to the Hawaiian mantle plume was also suggested by Harrison et al. (2020) based on the depleted Sr-Nd-Hf isotopic source of the Hawaiian rejuvenated lavas as well as the Ca-rich Hawaiian shield-stage basalts (DeFelice et al., 2019). Because carbonatite melts are stable in the mantle deeper than $\sim 90 \mathrm{~km}$ (e.g., Dobretsov and Shatskiy, 2012 and references therein), the impact of their percolation from the deep mantle/core would include a drastic fractionation of $\mathrm{Lu}$ / $\mathrm{Hf}$ in the carbonated mantle, potentially contributing to the decoupling of Nd-Hf isotope systematics. The strong Hf/Sm fractionation associated with REE fractionation relative to Hf is observed over only a limited range of $\mathrm{Sm} / \mathrm{Nd}$ fractionation in the carbonated mantle and carbonatite magmas (Fig. 5). Salt Lake Crater xenoliths, and other Hawaiian mantle xenolith series, exhibit such strongly decoupled Nd-Hf isotopes towards extremely radiogenic Hf (e.g., Bizimis et al., 2005, 2013 and references therein). This well-known isotopic feature reflects the time integration of $\mathrm{Hf}$ fractionation relative to REE and, as such, may result from longterm ( $\geq 1 \mathrm{Ga}$ ) recycling of depleted mantle components (e.g., Harrison et al., 2020 and references therein) but are also not incompatible with ancient core-mantle interaction recorded in the lower mantle.

Recycling of ancient sediments in the Hawaiian plume (Huang et al., 2011) could also be the source of carbon, however, their isotopically enriched source is not observed in the Hawaiian rejuvenated lavas (Béguelin et al., 2019). Furthermore, most studies on the SLC xenoliths from Oahu highlight several important geochemical and petrological features suggesting the existence of a deep (non-lithospheric) mantle source for the Hawaiian carbonatite melts (Sen et al., 1993; Keshav and Sen, 2001; Keshlav and Sen, 2003; Wirth and Rocholl, 2003; Keshlav and Sen, 2004; Bizimis et al., 2005; Frezzotti and Peccerillo, 2007; Bizimis and Peslier, 2015). Additionally, the southwestern (Kaula, Niihau, Oahu) group of the rejuvenated lavas demonstrates similarity of the Hf-isotope compositions to those of the Oahu xenoliths (Béguelin et al., 2019).

- The Oahu xenoliths include high-pressure cumulates related to
polybaric magma fractionation at depths $\geq 100 \mathrm{~km}$ (Keshlav and Sen,
2003, 2004; Keshav et al., 2007) and bear evidence of the deepest
majorite Grt reported from oceanic pyroxenites (e.g., Keshav and
Sen, 2001), with equilibration pressure of 6-9 GPa (i.e., $\sim 300-\mathrm{km}$ depth); the carbonatite melts may be generated even deeper (Thomson et al., 2016).

- The occurrence of pyroxene-hosted nano-diamonds inclusions in the garnet pyroxenite xenoliths (Frezzotti and Peccerillo, 2007; Wirth and Rocholl, 2003) strongly suggests a deep source for the primary carbonatite melts in the Hawaiian hot spot. The fact that some of the diamonds are found in basaltic glasses (Wirth and Rocholl, 2003) implies diamond genesis at $6 \mathrm{GPa}$ pressure and $1300{ }^{\circ} \mathrm{C}$ where carbonatite and basaltic melts are immiscibile (Hammouda, 2003).

- The mineralogy and trace-element characteristics of the SLC pyroxenite xenolith series suggests kimberlite veining (Keshlav and Sen, 2003) and/or carbonatite metasomatism, although some pyroxenites may relate to a different, lithospheric stage involving nephelenite melt-mantle (Sen et al., 2011), as suggested by Os-isotope compositions.

- Carbonatite-type melts are documented in the SLC lavas (Rocholl et al., 2015, 2019). Their carbonatite nature is consistent with the evidence for immisible "kimberlite melts" or carbonate-rich fluids/ melts found by Keshlav and Sen, 2003, Wirth and Rocholl (2003), Sen et al. (2005) and Frezzotti and Peccerillo (2007).

- The source of $\mathrm{H}_{2} \mathrm{O}$ and $\mathrm{CO}_{2}$ in the Hawaiian glasses, lavas and SLC pyroxenites (Dixon et al., 1997; Dixon and Clague, 2001; Bizimis and Peslier, 2015) may also ultimately derive from $\mathrm{H}_{2} \mathrm{O}$-bearing carbonatite melts. According to experimental models of Hammouda (2003) and Thomson et al. (2016), primary carbonatite melts can



Fig. 7. Pressure-temperature diagram showing stability fields relevant to carbonated mantle melting in the Hawaiian plume. Our model suggests that (1) carbonatites were generated after cooling of the Hawaiian plume during lowdegree partial melting of a recycled (lower) mantle source at depth of up to $9 \mathrm{GPa}$, as potentially documented by the SLC pyroxenite xenoliths; (2) these carbonatite melts led to flux melting of a hybrid pyroxenite-lherzolite mantle source at $>1100{ }^{\circ} \mathrm{C}$ and $>2 \mathrm{GPa}$ producing primitive, rejuvenated-stage Hawaiian lavas. HP: Hawaiian pyrolite; Cc: calcite. B05 refers to Bizimis et al. (2005) and KS04 and KS05 to Keshlav and Sen 2003, 2004. Adapted from Hammouda (2003). The potential effect of changes in the depth of melting and the extent of carbonatite metatomatism are shown by two arrows. Two arrows demonstrate: (1) increasing depths of partial melting and (2) increasing degrees of carbonatite fluxing. 
form from relatively low-temperature partial melting of recycled eclogitic material (assuming the presence of excess carbon) within the mantle transition zone where they may crystallize liquidus minerals such as diamonds due to carbonatite melt-peridotite reactions.

Based on the above considerations, our model proposes that the carbonated and ancient $(>1 \mathrm{Ga}$ ) recycled mantle or lower mantle source is involved in the Hawaiian plume. The process summarized in Fig. 7 occurred via low-solidus carbonatite melts produced from a deep $(\geq 9$ GPa) plume source, as inferred from the SLC garnet pyroxenite xenoliths, owing to the time lag after the post-shield stage (as it allows for the cooling of the plume). Subsequent metasomatic interactions in the asthenosphere occurred as these highly mobile carbon-rich melts rose within the plume at $>1100{ }^{\circ} \mathrm{C}$ and $>2 \mathrm{GPa}$. This carbonatitic melt fluxing led to melting of the hybrid (lherzolite/pyroxenite) source which produced the $\leq 4.2$ Ma Hawaiian rejuvenated-stage magmas. Our model also specifically explains why the Niihau and Oahu rejuvenated series are isotopically similar as part of the southwestern (Kaula, Niihau, Oahu) NOK group (Béguelin et al., 2019), but belong to different traceelement groups. This model is in line with existing Sr-Nd-Hf isotopic source of the Hawaiian rejuvenated lavas (Béguelin et al., 2019; Harrison et al., 2020), noble gas (Hanyu et al., 2005) and light stable isotope (Dixon et al., 2017) systematics of the Hawaiian hot spot, supporting the idea that the transfer of carbonatite melts to peridotite/pyroxenite may account for the geochemical characteristics of the oceanic island magmatism. Our model is also in line with model of Hofmann and Farnetani (2013) involving the thermal boundary layer as the principal source of the rejuvenated melting at the bottom of the mantle where heat is transported predominantly by conduction from the core into the mantle. Our model supports the idea about heterogeneity of the Hawaiian plume (e.g., Harrison et al., 2020).

\section{Conclusions}

We showed that primitive alkaline to transitional lavas series erupted during the recent $(\leq 4.2 \mathrm{Ma})$ rejuvenated stages of volcanic activity on the Hawaiian Islands are characterized by REE, Th and Ba enrichments relative to $\mathrm{K}, \mathrm{Zr}$, $\mathrm{Hf}$, and $\mathrm{Ti}$, incompatible with their derivation from an homogeneous mantle source. These characteristics are rather consistent with a hybrid (lherzolite-pyroxenite) asthenospheric source fluxed by carbonatitic melts as the latter, highly mobile, rose within the plume at $>1100{ }^{\circ} \mathrm{C}$ and $>2 \mathrm{GPa}$ while the variability in their major- and traceelement contents specify temporal variations in thermal regime, pyroxenite contribution and the extent of carbonatite metasomatism. We infered that the carbonatite melts were produced from low-solidus partial melting of deep sources ( $\geq 9 \mathrm{GPa}$ ) following the cooling of the plume after the postshield stage. Our observations along with existing Sr-Nd-Hf-Os isotope (e.g., Béguelin et al., 2019; Harrison et al., 2020), noble gas (Hanyu et al., 2005) and light stable isotope (Dixon et al., 2017) systematics of the Hawaiian lava and xenolith series suggest that carbonated sources in the Hawaiian mantle plume may be represented by an ancient $(>1 \mathrm{Ga}$ ) recycled depleted mantle and/or lower mantle component that had recorded core-mantle interactions. This scenario is in line with that of Hofmann and Farnetani (2013) involving the thermal boundary layer as the principal source of the rejuvenated melting at the bottom of the mantle where heat is transported predominantly by conduction from the core into the mantle. Our model further confirms the heterogeneity of the Hawaiian plume (e.g., Harrison et al., 2020) and supports the idea that the transfer of carbonatite melts and the involvement of mixed lithologies account for the geochemical characteristics of oceanic-island magmatism. Further investigations of the rejuvenated-stage Hawaiian magmatism coupled with seismic topography and geodynamic modeling are now important to further constrain such interaction processes and contribute to a better understanding of plume and core-mantle dynamics.

\section{Data availability statements}

Data are available through Clague and Frey (1982); Frey and Clague (1983); Chen and Frey (1985); Clague and Dalrymple (1988); Maaløe et al. (1992); Chen et al. (1991); Salters and Zindler (1995); Reiners and Nelson (1998); Frey et al. (2000); Dixon and Clague (2001); Clague and Moore (2002); Yang et al. (2003); Gaffney et al. (2004); Bizimis et al. (2004, 2005); Frey et al. (2005); Clague et al. (2006); Dixon et al. (2008); Cousens and Clague (2015); Phillips et al. (2016); and Garcia et al. (2016).

\section{Author contributions}

A.Y.B.: data compilation, conceptualization; investigation; methodology; project administration; writing. R.T.: OSM modeling, conceptualization; writing.

\section{Declaration of Competing Interest}

The authors declare that they have no known competing financial interests or personal relationships that could have appeared to influence the work reported in this paper.

\section{Acknowledgments}

We are grateful to L.V. Dmitriev, F.A. Frey, N. Mattielli, D. Weis, J. Scoates, V. Kamenetsky, M. Grégoire, M. Rabinowicz for their very helpful comments and suggestions, and to M.S.N. Carpenter for the English proofreading. Editor Arturo Gomez-Tuena, M. Bizimis and an anonymous reviewer are also thanked for their constructive criticism which significantly improved this paper. Romain Tilhac acknowledges a "Juan de la Cierva-formación" Fellowship (FJC2018-036729) granted by the Spanish Ministry of Science and Innovation and co-funded by the European Development Fund and the European Social Fund.

Appendix A. Estimation of trace-element ratios in partial melts relative to those of amphibole-bearing (A), phlogopite-bearing (P), and garnet (G) lherzolites and garnet pyroxenite (GP) sources

The values of $\mathrm{X} / \mathrm{Y}$ fractionation in a partial melt relative to $\mathrm{X} / \mathrm{Y}$ in the mantle source (Fig. 2) are calculated using the modal batch melting equation of Shaw (1970) (see Supplementary Models):

$$
\left([\mathrm{X}]_{\text {melt }} /[\mathrm{Y}]_{\text {melt }}\right) /\left([\mathrm{X}]_{\text {source }} /[\mathrm{Y}]_{\text {source }}\right)=\left[\mathrm{D}_{\mathrm{o}}^{\mathrm{Y}}+\mathrm{F}\left(1-\mathrm{D}_{\mathrm{o}}^{\mathrm{Y}}\right)\right] /\left[\mathrm{D}_{\mathrm{o}}{ }^{\mathrm{X}}+\mathrm{F}\left(1-\mathrm{D}_{\mathrm{o}}{ }^{\mathrm{X}}\right)\right]
$$

where $\mathrm{F}$ is degree of melting of the mantle source, $\mathrm{D}_{\mathrm{O}}$ corresponds to the bulk distribution coefficients, $[\mathrm{X}]$ and $[\mathrm{Y}]$ are concentrations of $\mathrm{X}$ and $\mathrm{Y}$ in the elemental ratio of $\mathrm{X}$ and $\mathrm{Y}$.

$\mathrm{D}_{\mathrm{o}}$ for $\mathrm{A}$ and $\mathrm{P}$ lherzolites are calculated using $\mathrm{K}_{\mathrm{d}}$ for Ol, Opx, Cpx, Amph and Phl (Table 2) and mineral compositions of A and P lherzolites taken from McKenzie and O'Nions (1991): 59.9\% Ol, 24.4\% Opx, 3.8\% Cpx, 11.6\% Amp (Phl). $\mathrm{D}_{\mathrm{o}}$ for G lherzolite are calculated using $\mathrm{K}_{\mathrm{d}}$ for Ol, Opx, Cpx and 
Grt (Table 2), mineral compositions of lherzolites taken from McKenzie and O'Nions (1991): G (59.8\% Ol, 21.1\% Opx, 7.6\% Cpx and 11.5\% Grt). $\mathrm{D}_{\mathrm{o}}$ for garnet pyroxenite (GP) are calculated using $\mathrm{K}_{\mathrm{d}}$ for Opx, Cpx, Grt (Table 2) and the following mineral compositions: 46.5\% Opx, 46.5\% Cpx, 7\% Grt (see Supplementary Models).

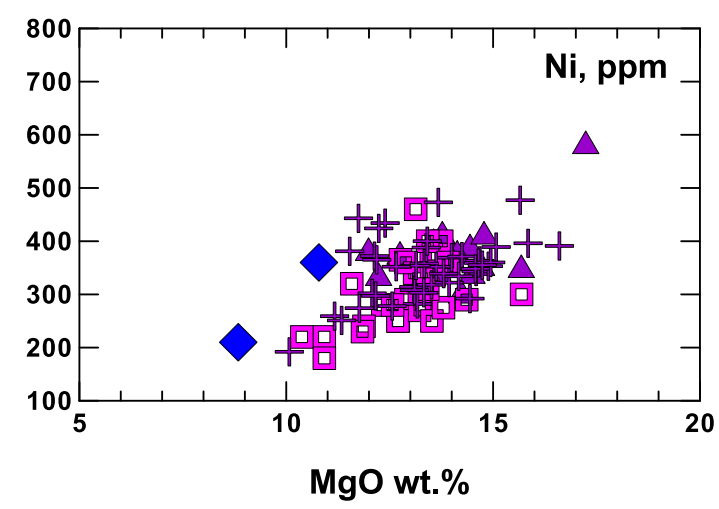

Fig. A1. $\mathrm{Ni}$ (in ppm) vs $\mathrm{MgO}$ (wt\%) contents in the Hawaiian alkaline lavas included in this study. Data sources as in Fig. 2.

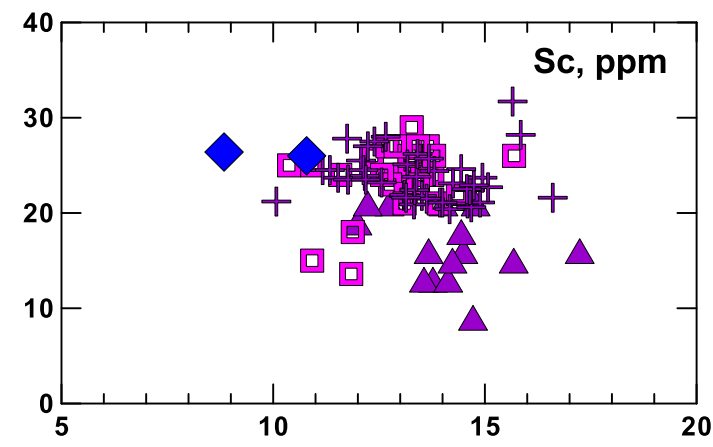

MgO wt.\%

Fig. A2. Sc (in ppm) vs $\mathrm{MgO}$ (wt\%) contents in the Hawaiian alkaline lavas included in this study. Data sources as in Fig. 2.

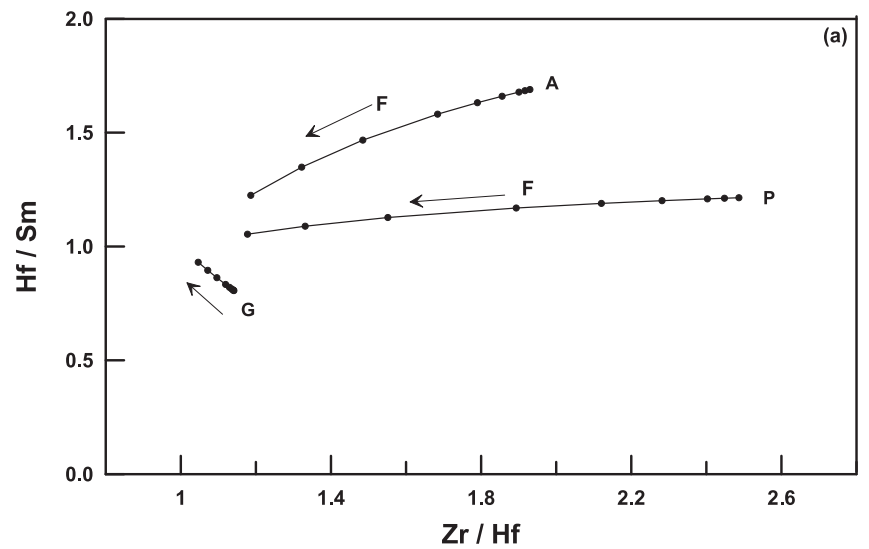

Fig. A3a. . Modeling of $\mathrm{Hf} / \mathrm{Sm}$ vs $\mathrm{Zr} / \mathrm{Hf}$ behavior during batch modal melting of uncarbonated garnet, amphibole and phlogopite lherzolites. A - amphibole lherzolite, P - phlogopite lherzolite and G - garnet lherzolite. Arrows indicate the increasing degree of melting (F). 


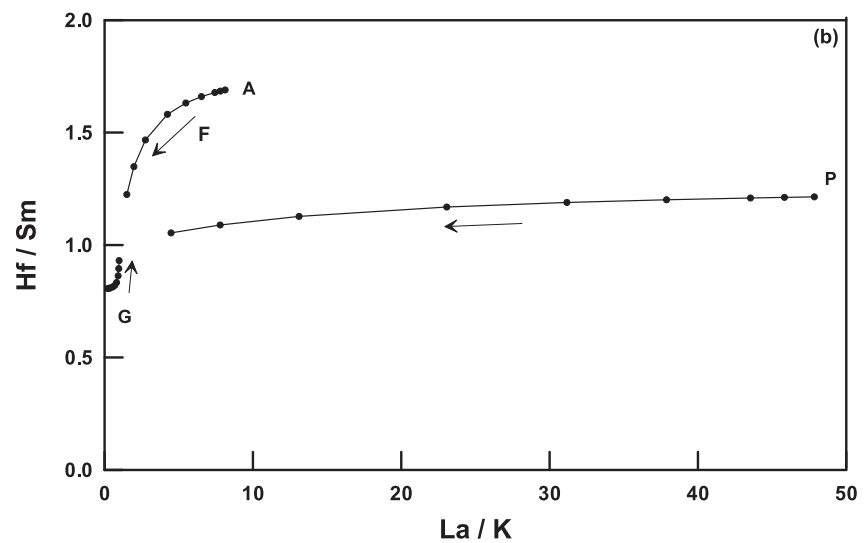

Fig. A3b. Modeling of Hf/Sm $v s \mathrm{La} / \mathrm{K}$ behavior during batch modal melting of uncarbonated garnet, amphibole and phlogopite lherzolites. A - amphibole lherzolite, $\mathrm{P}$ - phlogopite lherzolite and G - garnet lherzolite. Arrows indicate the increasing degree of melting (F).

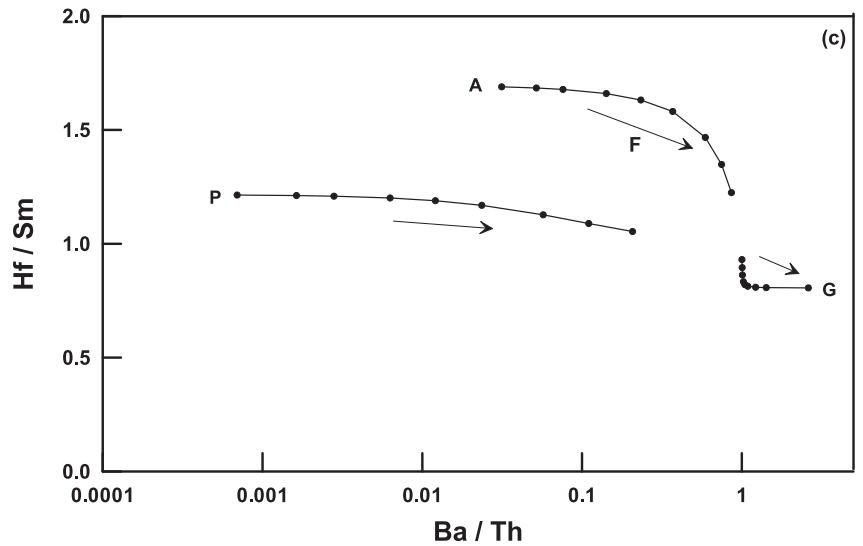

Fig. A3c. Modeling of $\mathrm{Hf} / \mathrm{Sm} v s \mathrm{Ba} / \mathrm{Th}$ behavior during batch modal melting of uncarbonated garnet, amphibole and phlogopite lherzolites. A - amphibole lherzolite, P - phlogopite lherzolite and G - garnet lherzolite. Arrows indicate the increasing degree of melting (F).

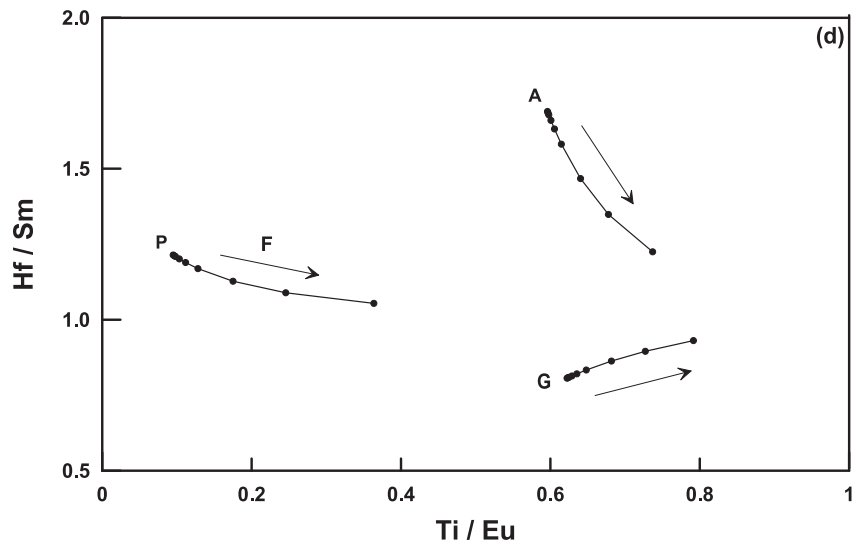

Fig. A3d. Modeling of Hf/Sm $v s \mathrm{Ti} / \mathrm{Eu}$ behavior during batch modal melting of uncarbonated garnet, amphibole and phlogopite lherzolites. A - amphibole lherzolite, $\mathrm{P}$ - phlogopite lherzolite and G - garnet lherzolite. Arrows indicate the increasing degree of melting (F).

\section{Appendix B. Supplementary data}

Supplementary data to this article can be found online at https://doi.org/10.1016/j.earscirev.2021.103819.

\section{References}

Adam, J., Green, T.H., 1994. The effect of pressure and temperature on the partitioning of Ti, Sr and REE between amphibole, Cpx and basanitic melts. Chem. Geol. 117, 219-233.

Adam, J., Green, T.H., 2006. Trace element partitioning between mica- and amphibolebearing garnet lherzolite and hydrous basanite melt: 1 . Experimental results and the investigation of controls on partitioning behaviour. Contrib. Mineral. Petrol. 152, $1-17$.

Adam, J., Green, T.H., Sie, S.H., 1993. Proton microprobe determined partitioning of Rb, $\mathrm{Sr}, \mathrm{Ba}, \mathrm{Y}, \mathrm{Zr}, \mathrm{Nb}$, and Ta between experimentally produced amphiboles and silicate melts with variable F content. Chem. Geol. 109, 29-49.

Allègre, C.J., Pineau, F., Bernat, M., Javoy, M., 1971. Geochemical evidence for the occurence of carbonatites on the Cape Verde and Canary Islands. Nature 233, 103. 
Anderson, K.R., Poland, M.P., 2017. Abundant carbon in the mantle beneath Hawai'i. Nat. Geosci. 10, 704-708.

Ashley, A.W., Bizimis, M., Peslier, A.H., Jackson, M., Konter, J.G., 2020. Metasomatism and hydration of the oceanic lithosphere: a case study of peridotite xenoliths from Samoa. J. Petrol. 61, 1-29.

Baker, M.B., Wyllie, P.J., 1992. High-pressure apatite solubility in carbonatite-rich liquids: Implications for mantle metasomatism. Geochim. Cosmochim. Acta 56, 3409-3422.

Barrera, J.L., Fernandez, S.S., Fuster, J.M., Ibarrola, E., 1981. Ijolitas-sienitascarbonatitas de los macizos del norte del complejo plutonico basal de Fuerteventura (Islas Canarias). Bol. Geol. Min. (Madrid) 92, 309-321.

Beattie, P., 1993. The generation of uranium series disequilibria by partial melting of Spl peridotite: Constraints from partitioning studies. Earth Planet. Sci. Lett. 117, 379-391.

Beccaluva, L., Barbiery, M., Born, H., Brotzu, P., Coltorti, M., Conte, A., Garbarino, C., Gomes, C.B., Macciotta, G., Morbidelli, L., Ruberti, E., Siena, F., Traversa, G., 1992 Fractional crystallisation and liquid immiscibility processes in the alkalinecarbonatite complex of Juqui (Seo Paulo, Brazil). J. Petrol. 33, 1371-1404.

Béguelin, P., Bizimis, M., McIntosh, E.C., Cousens, B., Clague, D.A., 2019. Sources vs processes: unraveling the compositional heterogeneity of rejuvenated-type Hawaiian magmas. Earth Planet. Sci. Lett. 514, 119-129.

Bizimis, M., Griselin, M., Lassiter, J.C., Salters, V.J.M., Sen, G., 2007. Ancient recycled mantle lithosphere in the Hawaiian plume: Osmium-Hafnium isotopic evidence from peridotite mantle xenoliths. Earth Planet. Sci. Lett. 257 (1-2), 259-273. https://doi.org/10.1016/j.epsl.2007.02.036.

Bizimis, M., Peslier, A.H., 2015. Water in Hawaiian garnet pyroxenites: Implications for water heterogeneity in the mantle. Chem. Geol. 397, 61-75.

Bizimis, M., Sen, G., Salters, V.J.M., 2004. Hf-Nd isotope decoupling in the oceanic lithosphere: constraints from Spl peridotites from Oahu, Hawaii. Earth Planet. Sci. Lett. 217 (Issues 1-2), 43-58. https://doi.org/10.1016/S0012-821X(03)00598-3.

Bizimis, M., Sen, G., Salters, V.J.M., Keshav, S., 2005. Hf-Nd-Sr isotope systematics of garnet pyroxenites from SLC, Oahu, Hawaii: evidence for a depleted component in Hawaiian volcanism. Geochim. Cosmochim. Acta 69, 2629-2646.

Bizimis, M., Salters, V.J.M., Garcia, M.O., Norman, M.D., 2013. The composition and distribution of the rejuvenated component across the Hawaiian plume: Hf-Nd-Sr-Pb isotope systematics of Kaula lavas and pyroxenite xenoliths. Geochem. Geophys. Geosyst. 14, 4458-4478. https://doi.org/10.1002/ggge.20250.

Blundy, J.D., Robinson, J.A.C., Wood, B.J., 1998. Heavy REE are compatible in Cpx on the Spl lherzolite solidus. Earth Planet. Sci. Lett. 160, 493-504.

Bobrov, A.V., Litvin, Y.A., Kuryura, A.V., Dymshits, A.M., Jeffries, T., Bindi, L., 2014. Partitioning of trace elements between Na-bearing majoritic garnet and melt at 8.5 $\mathrm{GPa}$ and $1500-1900^{\circ} \mathrm{C}$. Lithos $189,159-166$.

Borghini, G., Fumagalli, P., 2020. Melting relations of anhydrous Ol-free pyroxenite Px1 at 2 GPa. Eur. J. Mineral. 32, 251-264. https://doi.org/10.5194/ejm-32-251-2020.

Borisova, A.Y., Bohrson, W.A., Grégoire, M., 2017. Origin of primitive ocean island basalts by crustal gabbro assimilation and multiple recharge of plume-derived melts. Geochem. Geophys. Geosyst. https://doi.org/10.1002/2017GC006986.

Brenan, J.M., Watson, E.B., 1991. Partitioning of trace elements between carbonatite melt and Cpx and $\mathrm{Ol}$ at mantle P-T conditions. Geochim. Cosmochim. Acta 55, 2203-2214.

Brenan, J.M., Shaw, H.F., Ryerson, F.J., Phinney, D.L., 1995. Experimental determination of trace - element partitioning between pargasite and synthetic hydrous andesitic melt. Earth Planet. Sci. Lett. 135, 1-11.

Chen, C.-Y., Frey, F.A., 1985. Trace element isotopic geochemistry of lavas from Haleakala volcano, East Maui, Hawaii: Implications for the origin of Hawaian basalts. J. Geophys. Res. 90 (B10), 8743-8768.

Chen, C.-Y., Frey, F.A., Garcia, M.O., Dalrymple, G.B., Hart, S.R., 1991. The tholeiite to alkalic basalt transition at Haleakala Volcano, Maui, Hawaii. Contrib. Mineral. Petrol. 106, 183-200.

Clague, D.A., 1987a. Hawaiian xenolith populations, magma supply rates, and development of magma chambers. Bull. Volcanol. 49, 577-587.

Clague, D.A., 1987b. Hawaiian alkaline volcanism. In: Fitton, J.G., Upton, B.G.J. (Eds.), Alkaline Igneous Rocks, 30. Geol. Soc. London Spec. Publ, pp. 227-252.

Clague, D.A., Dalrymple, G.B., 1988. Age and petrology of alkalic postshield and rejuvenated-stage lava from Kauai, Hawaii. Contrib. Mineral. Petrol. 99, 202-218.

Clague, D.A., Frey, F.A., 1982. Petrology and trace element geochemistry of the Honolulu Volcanics, Oahu: Implications for the oceanic mantle below Hawaii. J. Petrol. 23, 447-504.

Clague, D.A., Moore, J.G., 2002. The proximal part of the giant submarine Wailau landslide, Molokai, Hawaii. J. Volcanol. Geotherm. Res. 113 (1-2), 259-287. https://doi.org/10.1016/S0377-0273(01)00261-X.

Clague, D.A., Paduan, J.B., McIntosh, W.C., Cousens, B.L., Davis, A.S., Reynolds, J.R., 2006. A submarine perspective of the Honolulu Volcanics, Oahu. J. Volcanol. Geotherm. Res. 151, 279-307.

Class, C., Goldstein, S.L., 1997. Plume-lithosphere interactions in the ocean basins: constraints from the source mineralogy. Earth Planet. Sci. Lett. 150, 245-260.

Class, C., Goldstein, S.L., Altherr, R., Bachelery, P., 1998. The process of plumelithosphere interactions in the ocean basin - the case of Grand Comore. J. Petrol. 39, 881-903.

Coltorti, M., Bonadiman, C., Hinton, R.W., Siena, F., Upton, B.G.J., 1999. Carbonatite metasomatism of the oceanic upper mantle: evidence from Cpxs and glasses in ultramafic xenoliths of Grande Comore, Indian Ocean. J. Petrol. 40, 133-165.

Corgne, A., Armstrong, L.S., Keshav, S., Fei, Y., McDonough, W.F., Minarik, W.G., Moreno, K., 2012. Trace element partitioning between majoritic garnet and silicate melt at 10-17GPa: implications for deep mantle processes. Lithos 148, 128-141. https://doi.org/10.1016/j.lithos.2012.06.013.
Corgne, A., Wood, B.J., 2004. Trace element partitioning between majoritic garnet and silicate melt at 25GPa. Phys. Earth Planet. Inter. 143-144, 407-419. https://doi.org/ 10.1016/j.pepi.2003.08.012.

Cousens, B.L., Clague, D.A., 2015. Shield to rejuvenated stage volcanism on Kauai and Niihau, Hawaiian Islands. J. Petrol. 56, 1547-1584.

Cox, K.G., Bell, J.D., Pankhurst, R.J., 1979. The Interpretation of Igneous Rocks. Allen \& Unwin, London, p. 450.

Dalou, C., Koga, K.T., Hammouda, T., Poitrasson, F., 2009. Trace element partitioning between carbonatitic melts and mantle transition zone minerals: implications for the source of carbonatites. Geochim. Cosmochim. Acta 73 (1), 239-255. https://doi.org/ 10.1016/j.gca.2008.09.020

Dalton, J.A., Wood, B.J., 1993. The composition of primary carbonatite melts and their evolution through wallrock reaction in the mantle. Earth Planet. Sci. Lett. 119, $511-525$.

Dasgupta, R., Walke, D., 2008. Carbon solubility in core melts in a shallow magma ocean environment and distribution of carbon between the Earth's core and the mantle. Geochim. Cosmochim. Acta 72, 4627-4641.

Dasgupta, R., Hirschmann, M.N., Withers, A.C., 2004. Deep global cycling of carbon constrained by the solidus of anhydrous, carbonated eclogite under upper mantle conditions. Earth Planet. Sci. Lett. 227, 73-85.

Dasgupta, R., Hirschmann, M.M., McDonough, W.F., Spiegelman, M., Withers, A.C., 2009. Trace element partitioning between garnet lherzolite and carbonatite at 6.6 and $8.6 \mathrm{GPa}$ with applications to the geochemistry of the mantle and of mantlederived melts. Chem. Geol. 262, 57-77.

David, K., Schiano, P., Allègre, C.J., 2000. Assessment of Zr/Hf fractionation in oceanic basalts and continental materials during petrogenetic processes. Earth Planet. Sci. Lett. 178, 285-301.

De Vivo, B., Frezzotti, M.L., Lima, A., Trigila, R., 1988. Spl lherzolite nodules from Oahu island (Hawaii): a fluid inclusion study. Bull. Mineral. 111, 307-319.

DeFelice, C., Mallick, S., Saal, A.E., Huang, S., 2019. An isotopically depleted lower mantle component is intrinsic to the Hawaiian mantle plume. Nat. Geosci. 12, 487-492. https://doi.org/10.1038/s41561-019-0348-0.

Dixon, J.E., Clague, D.A., 2001. Volatiles in basaltic glasses from Loihi Seamount, Hawaii: evidence for a relatively dry plume component. J. Petrol. 42, 627-654.

Dixon, J.E., Clague, D.A., Wallace, P., Poreda, R., 1997. Volatiles in alkalic basalts from the North Arch volcanic field, Hawaii: extensive degassing of deep submarineerupted alkalic series lavas. J. Petrol. 38, 911-939.

Dixon, J., Clague, D.A., Cousens, B., Monsalve, M.L., Uhl, J., 2008. Carbonatite and silicate melt metasomatism of the mantle surrounding the Hawaiian plume: evidence from volatiles, trace elements, and radiogenic isotopes in rejuvenated-stage lavas from Niihau, Hawaii. Geochem. Geophys. Geosyst. 9, Q09005 https://doi.org/ 10.1029/2008GC002076.

Dixon, J., Bindeman, I.N., Kingsley, R.H., Simons, K.K., Le Roux, P.J., Hajewski, T.R., Swart, P., Langmuir, C.H., Ryan, J.G., Walowski, K.J., Wada, I., Wallace, P.J., 2017. Light stable isotope compositions of enriched mantle sources: resolving the dehydration paradox. Geochem. Geophys. Geosyst. 18. https://doi.org/10.1002/ 2016GC006743.

Dobretsov, N.L., Shatskiy, A.F., 2012. Deep carbon cycle and geodynamics: the role of the core and carbonatite melts in the lower mantle. Russ. Geol. Geophys. 53 1117-1132.

Dunn, T., 1987. Partitioning of Hf, Lu, Ti and Mn between Ol, Cpx and basaltic liquid. Contrib. Mineral. Petrol. 96, 476-484.

Dupuy, C., Liotard, J.M., Dostal, J., 1992. Zr/Hf fractionation in intraplate basaltic rocks: Carbonate metasomatism in the mantle source. Geochim. Cosmochim. Acta 56, $2417-2423$.

Eggins, S.M., 1992. Petrogenesis of Hawaiian tholeiites: 2, aspects of dynamic melt segregation. Contrib. Mineral. Petrol. 110, 398-410.

Eggler, D.H., 1989. Carbonatites, primary melts and mantle dynamics. In: Bell, Keith (Ed.), Carbonatites: Genesis and Evolution. Unwin Hyman, London, pp. 561-580.

Elkins, L.J., Gaetani, G.A., Sims, K.W.W., 2008. Partitioning of U and Th during garnet pyroxenite partial melting: Constraints on the source of alkaline ocean island basalts, Earth Planet. Sci. Lett. 265, 270-286.

Falloon, T.J., Green, D.H., 1989. The solidus of carbonated, fertile peridotite. Earth Planet. Sci. Lett. 94, 364-370.

Falloon, T.J., Green, D.H., Hatton, C.J., Harris, K.L., 1988. Anhydrous partial melting of a fertile and depleted peridotite from 2 to $30 \mathrm{~kb}$ and application to basalt petrogenesis. J. Petrol. 29, 1257-1288.

Fekiacova, Z., Abouchami, W., Galer, S.J.G., Garcia, M.O., Hofmann, A.W., 2007. Origin and temporal evolution of Ko'olau Volcano, Hawai'i: Inferences from isotope data on the Koolau Scientific Drilling Project (KSDP), the Honolulu Volcanics and ODP Site843. Earth Planet. Sci. Lett. 261 (1-2), 65-83.

Foley, S.F., Jenner, G.A., 2004. Trace element partitioning in lamproitic magmas - the Gaussberg Ol leucite. Lithos 75, 19-38.

Frey, F.A., 1980. The origin of pyroxenites and garnet pyroxenites from SLC, Oahu, Hawaii: trace element evidence. Am. J. Sci. 280-A, 427-449.

Frey, F.A., Clague, D.A., 1983. Geochemistry of diverse basalt types from Loihi Seamount, Hawaii: petrogenetic implications. Earth Planet. Sci. Lett. 66, 337-355.

Frey, F.A., Clague, D., Mahoney, J.J., Sinton, J.M., 2000. Volcanism at the edge of the Hawaiian plume: Petrogenesis of submarine alkali lavas from the North Arch volcanic field. J. Petrol. 41, 667-691.

Frey, F.A., Huang, S., Blichert-Toft, J., Regelous, M., Boyet, M., 2005. Origin of depleted components in basalt related to the Hawaiian Hotspot: evidence from isotopic and Incompatible element ratios. Geochem. Geophys. Geosyst. 6, Q02L07. https://doi. org/10.1029/2004GC000757.

Frezzotti, M.-L., Peccerillo, A., 2007. Diamond-bearing COHS fluids in the mantle beneath Hawaii. Earth Planet. Sci. Lett. 262, 273-283. 
Frezzotti, M.L., Burke, E.A.J., De Vito, B., Stefanini, B., Villa, I.M., 1992. Mantle fluids in pyroxenite nodules from SLC (Oahu, Hawaii). Eur. J. Mineral. 4, 1137-1153.

Gaetani, G.A., Kent, A.J.R., Grove, T.L., Hutcheon, I.D., Stolper, E.M., 2003. Mineral/ melt partitioning of trace elements during hydrous peridotite melting. Contrib. Mineral. Petrol. 145, 391-405.

Gaffney, A.M., Nelson, B.K., Blichert-Toft, J., 2004. Geochemical constraints on the role of oceanic lithosphere in intra-volcano heterogeneity at West Maui, Hawaii. J. Petrol. 45, 1663-1687.

Garcia, M.O., Presti, A.A., 1987. Glass in garnet pyroxenite xenoliths from Kaula Island, Hawaii. Geology 15, 904-906.

Garcia, M.O., Frey, F.A., Grooms, D.G., 1986. Petrology of volcanic rocks from Kaula Island, Hawaii. Contrib. Mineral. Petrol. 94, 461-471.

Garcia, M.O., Swinnard, L., Weis, D., Greene, A.R., Tagami, T., Sano, H., Gandy, C.E., 2010. Petrology, geochemistry and geochronology of Kaua'i lavas over 45 Myr: Implications for the origin of rejuvenated volcanism and the evolution of the Hawaiian plume. J. Petrol. 51, 1507-1540.

Garcia, M.O., Weis, D., Jicha, B.R., Ito, G., Hanano, D., 2016. Petrology and geochronology of lavas from Ka'ula Volcano: Implications for rejuvenated volcanism of the Hawaiian mantle plume. Geochim. Cosmochim. Acta 185, 278-301. https:// doi.org/10.1016/j.gca.2016.03.025.

Gerlach, D.C., Cliff, R.A., Davies, G.R., Norry, M., Hodgson, N., 1988. Magma sources of the Cape Verde Archipelago: isotopic and trace element constraints. Geochim. Cosmochim. Acta 52, 2979-2992.

Green, T.H., 1994. Experimental studies of trace-element partitioning applicable to igneous petrogenesis - Sedona 16 years later. Chem. Geol. 117, 1-36.

Green, D.H., Wallace, M.E., 1988. Mantle metasomatism by ephemeral carbonatite melts. Nature 336, 459-462.

Green, T.H., Blundy, J.D., Adam, J., Yaxley, G.M., 2000. SIMS determination of trace element partition coefficients between garnet, $\mathrm{Cpx}$ and hydrous basaltic liquids at 2-7.5 GPa and $1080-1200^{\circ} \mathrm{C}$. Lithos 53, 165-187.

Grégoire, M., Moine, B.N., O'Reilly, S.Y., Cottin, J.Y., Giret, A., 2000. Trace element residence and partitioning in mantle xenoliths metasomatised by highly alkaline, silicate- and carbonate-rich melts (Kerguelen Islands, Indian Ocean). J. Petrol. 41, 477-509.

Guillou, H., Garcia, M.O., Turpin, L., 1997. Unspiked K-Ar dating of young volcanic rocks from Loihi and Pitcaim hot spot seamounts. J. Volcanol. Geotherm. Res. 78, 239-249.

Gurriet, P., 1987. A thermal model for the origin of post-erosional alkalic lava, Hawaii. Earth Planet. Sci. Lett. 82, 153-158.

Hammouda, T., 2003. High-pressure melting of carbonated eclogite and experimental constraints on carbon recycling and storage in the mantle. Earth Planet. Sci. Lett. 214, 357-368.

Hanyu, T., Clague, D.A., Kaneoka, I., Dunai, T.J., Davies, G.R., 2005. Noble gas systematics of submarine alkali lavas near the Hawaiian hotspot. Chem. Geol. 214, 135-155.

Harmer, R.E., Gittins, J., 1998. The case for primary, mantle-derived carbonatite magma J. Petrol. 39, 1895-1903.

Harrison, L.N., Weis, D., Garcia, M.O., 2020. The multiple depleted mantle components in the Hawaiian-Emperor chain. Chem. Geol. 532, 119324.

Hart, S.R., Dunn, T., 1993. Experimental cpx / melt partitioning of 24 trace elements. Contrib. Mineral. Petrol. 113, 1-8.

Hassler, D.R., 1999. Plume-lithosphere interaction: geochemical evidence from upper mantle and lower crustal xenoliths from the Kerguelen Islands. Ph. D. thesis. Massachusetts Institute of Technology Cambridge, Woods Hole Oceanographic Institution, Woods Hole, Massachusetts, p. 370.

Hauri, E.H., Shimizu, N., Dieu, J.J., Hart, S.R., 1993. Evidence for hotspot-related carbonatite metasomatism in the oceanic upper mantle. Nature 365, 221-226.

Hauri, E.H., Wagner, T.P., Grove, T.L., 1994. Experimental and natural partitioning of $\mathrm{Th}, \mathrm{U}, \mathrm{Pb}$ and other trace elements between garnet, Cpx and basaltic melts. Chem. Geol. 117, 149-166.

Hirose, K., 1997. Partial melt composition of carbonated peridotite at $3 \mathrm{GPa}$ and the role of $\mathrm{CO}_{2}$ in alkali-basalt generation. Geophys. Res. Lett. 24, 2837-2840.

Hirschmann, M.M., Stolper, E.M., 1996. A possible role for garnet pyroxenite in the origin of the "garnet signature" in MORB. Contrib. Mineral. Petrol. 124, 185-208.

Hoernle, K., Tilton, G., Le Bas, M.J., Duggen, S., Garbe-Schönberg, D., 2002. Geochemistry of oceanic carbonatites compared with continental carbonatites: mantle recycling of oceanic crustal carbonate. Contrib. Mineral. Petrol. 142, 520-542.

Hofmann, A.W., Farnetani, C.G., 2013. Two views of Hawaiian plume structure. Geochem. Geophys. Geosyst. 14, 5308-5322. https://doi.org/10.1002/ 2013GC004942.

Hofmann, A.W., Farnetani, C.G., Spiegelman, M., Class, C., 2011. Displaced helium and carbon in the Hawaiian plume. Earth Planet. Sci. Lett. 312, 226-236.

Huang, S., Farkaš, J., Jacobsen, S.B., 2011. Stable calcium isotopic compositions of Hawaiian shield lavas: evidence for recycling of ancient marine carbonates into the mantle. Geochim. Cosmochim. Acta 75, 4987-4997. https://doi.org/10.1016/j. gca.2011.06.010

Ionov, D.A., Dupuy, C., O'Reilly, S.Y., Kopylova, M.G., Genshaft, Y.S., 1993. Carbonated peridotite xenoliths from Spitsbergen: Implication for trace element signatute of mantle carbonate metasomatism. Earth Planet. Sci. Lett. 119, 283-297.

Irving, A.J., Frey, F.A., 1984. Trace element abundances in megacrysts and their host basalts: Constraints on partition coefficients and megacryst genesis. Geochim. Cosmochim. Acta 47, 1201-1221.

Iwamori, H., 1994. ${ }^{238} \mathrm{U}-{ }^{230} \mathrm{Th}-{ }^{226} \mathrm{Ra}$ and ${ }^{235} \mathrm{U}-{ }^{231} \mathrm{~Pa}$ disequilibria produced by mantle melting with porous and channel flows. Earth Planet. Sci. Lett. 125 (1-4), 1-16. https://doi.org/10.1016/0012-821X(94)90203-8.
Jochum, K.P., McDonough, W.F., Palme, H., Spettel, B., 1989. Compositional constraints on the continental lithospheric mantle from trace elements in Spl peridotite xenoliths. Nature 340, 548-550.

Johnson, K.T.M., 1994. Experimental cpx / and garnet / melt partitioning of REE and other trace elements at high pressure: Petrogenesis implication. Goldschmidt Conference Edinburg. Mineral. Mag. 58A, 454-455.

Kelemen, P.B., Shimizu, N., Dunn, T., 1993. Relative depletion of niobium in some arc magmas and the continental crust: partitioning of $\mathrm{K}, \mathrm{Nb}$, La and Ce during melt/rock reaction in upper mantle. Earth Planet. Sci. Lett. 120, 111-134.

Keshav, S., Sen, G., 2001. Majoritic garnets in Hawaiian Xenoliths: preliminary results. Geophys. Res. Lett. 28, 3509-3512. https://doi.org/10.1029/2001GL012950.

Keshav, S., Sen, G., Presnall, D.C., 2007. Garnet-bearing Xenoliths from SLC, Oahu, Hawaii: High-pressure fractional crystallization in the Oceanic Mantle. J. Petrol. 48, 1681-1724. https://doi.org/10.1093/petrology/egm035.

Keshlav, S., Sen, G., 2003. A rare composite xenolith from SLC, Oahu: high-pressure fractionation and implications for kimberlitic melts in the Hawaiian mantle. Contrib. Mineral. Petrol. 144, 548-558.

Keshlav, S., Sen, G., 2004. The depth of magma fractionation in the oceanic mantle: Insights from garnet- bearing xenoliths from Oahu, Hawaii. Geophys. Res. Lett. 31, L04611 https://doi.org/10.1029/2003GL018990.

Klemme, S., van der Laan, S.R., Foley, S.F., Gunther, D., 1995. Experimentally determined trace and minor element partitioning between Cpx and carbonatite melt under upper mantle conditions. Earth Planet. Sci. Lett. 133, 439-448.

Kogarko, L.N., Henderson, C.M.B., Pacheco, H., 1995. Primary Ca-rich carbonatite magma and carbonate-silicate-sulphide liquid immiscibility in the upper mantle. Contrib. Mineral. Petrol. 121, 267-274.

Kogarko, L.N., Kurat, G., Taflos, T., 2001. Carbonate metasomatism of the oceanic mantle beneath Fernando de Noronha Island, Brazil. Contrib. Mineral. Petrol. 140, 577-587. https://doi.org/10.1007/s004100000201.

Lambart, S., Baker, M.B., Stolper, E.M., 2016. The role of pyroxenite in basalt genesis: Melt-PX, a melting parameterization for mantle pyroxenites between 0.9 and $5 \mathrm{GPa}$. J. Geophys. Res. Solid Earth 121, 5708-5735. https://doi.org/10.1002/ 2015JB012762.

Lanphere, M.A., Dalrymple, G.B., 1980. Age and strontium isotope composition of the Honolulu volcanic series, Oahu, Hawaii. Am. J. Sci. 280-A, 736-751.

Lassiter, J.C., Hauri, E.H., Reiners, P.W., Garcia, M.O., 2000. Generation of Hawaiian post-erosional lavas by melting of a mixed lherzolite/pyroxenite source. Earth Planet. Sci. Lett. 178, 269-284.

LaTourette, T., Hervig, R.L., Holloway, J.R., 1995. Trace element partitioning between amphibole, phlogopite, and basanite melt. Earth Planet. Sci. Lett. 135, 13-30.

Liu, M., Chase, C.G., 1991. Evolution of Hawaiian basalts: a hotspot melting model. Earth Planet. Sci. Lett. 104, 151-165.

Maaløe, S., James, D., Smedley, P., Peterson, S., Garmann, L.B., 1992. The Koloa volcanic suite of Kauai, Hawaii. J. Petrol. 33, 761-784.

Mattielli, N., Weis, D., Scoates, J.S., Shimizu, N., Mennessier, J.-P., Grégoire, M., Cottin, J.-Y., Giret, A., 1999. Evolution of heterogeneous lithospheric mantle in a plume environment beneath the Kerguelen Archipelago. J. Petrol. 40, 1721-1744.

McKenzie, D., O'Nions, R.K., 1991. Partial melt distributions from inversion of rare earth element concentrations. J. Petrol. 32, 1021-1091.

Meen, J.K., Ayers, J.C., Fregeau, E.J., 1989. A model of mantle metasomatism by carbonated alkaline melts; trace element and isotopic compositions of mantle source regions of carbonatite and other continental igneous rocks. In: Bell, Keith (Ed.), Carbonatites: Genesis and Evolution. Unwin Hyman, London, pp. 164-495.

Nelson, D.R., Chivas, A.R., Chappell, B.W., McCulloch, M.T., 1988. Geochemical an isotopic systematics in carbonatites and implications for the evolution of oceanisland sources. Geochim. Cosmochim. Acta 52, 1-17.

Nixon, P.H., Boyd, F.R., 1979. Garnet-bearing lherzolites and discrete nodule series from the Malaita alnoite, Solomon Islands, SW Pacific, and their bearing on oceanic mantle composition and geotherm. In: Boyd, F.R., Meyer, H.O.A. (Eds.), The Mantle Samples. Amer.Geophys.Union Monogr, Washington, pp. 400-423.

Oliveira, B., Afonso, J.C., Tilhac, R., 2020. A disequilibrium reactive transport model for mantle magmatism. J. Petrol. 61-9, egaa067.

Ozawa, K., 2001. Mass balance equations for open magmatic systems: Trace element behavior and its application to open system melting in the upper mantle. J. Geophys. Res. 106 (B7), 13407-13434. https://doi.org/10.1029/2001JB900001.

Peslier, A.H., Bizimis, M., 2015. Water in Hawaiian peridotite minerals: A case for a dry metasomatized oceanic mantle lithosphere. Geochem. Geophys. Geosyst. 16, 1211-1232. https://doi.org/10.1002/2015GC005780.

Phillips, E.H., Sims, K.W.W., Sherrod, D.R., Salters, V.J.M., Blusztajn, J., Dulai, H., 2016. Isotopic constraints on the genesis and evolution of basanitic lavas at Haleakala, Island of Maui, Hawaii. Geochim. Cosmochim. Acta 195, 201-225. https://doi.org/ 10.1016/j.gca.2016.08.017.

Pilet, S., 2015. Generation of low-silica alkaline lavas: petrological constraints, models, and thermal implications. In: Foulger, G.R., Lustrino, M., King, S.D. (Eds.), The Interdisciplinary Earth: A Volume in Honor of Don L. Anderson: Geological Society of America Special Paper 514 and American Geophysical Union Special Publication 71. American Geophysical Union, pp. 281-304 doi:10.1130/2015.2514(17).

Reiners, P.W., Nelson, B.K., 1998. Temporal-compositional-isotopic trends in rejuvenated-stage magmas of Kauai, Hawaii, and implications for mantle melting process. Geochim. Cosmochim. Acta 62, 2347-2368.

Remaidi, M., 1993. Etude petrologique et geochimique d'une association peridotites refractaires - pyroxenites dans le massif de Ronda (Espagne). Ph. D. Thesis, Academie de Monpellier. Universite Monpellier II. Sciences et Techniques du Languedoc.

Rizo, H., Andrault, D., Bennett, N.R., Humayun, M., Brandon, A., Vlastelic, I., Moine, B., Poirier, A., Bouhifd, M.A., Murphy, D.T., 2019. ${ }^{182} \mathrm{~W}$ evidence for core-mantle 
interaction in the source of mantle plumes. Geochem. Persp. Let. 11, 6-11. https:// doi.org/10.7185/geochemlet.1917.

Rocholl, A., Jochum, K.P., Plessen, B., Rhede, D., Romer, R.L., Wirth, R., 2015. First Report on Hawaiian Carbonatites. Goldschmidt Conference, Abstract.

Rocholl, A., Rhede, D., Klügel, A., Jochum, K.P., Wirth, R., 2019. Impact of Hawaiian Carbonatites on HVS Rejuvenation-Stage Volcanism. Goldschmidt Conference. Abstract.

Rudnick, R.L., McDonough, W.F., Chappell, B.W., 1993. Carbonatite metasomatism in the northern Tanzanian mantle: Petrographic and geochemical characteristics. Earth Planet. Sci. Lett. 114, 463-475.

Salters, V.J.M., Shimizu, N., 1988. World-wide occurrence of HFSE-depleted mantle. Geochim. Cosmochim. Acta 52, 2177-2182.

Salters, V.J.M., Zindler, A., 1995. Extreme ${ }^{176} \mathrm{Hf} /{ }^{177} \mathrm{Hf}$ in the sub-oceanic mantle. Earth Palnet Sci. Lett. 129, 13-30.

Schiano, P., Clocchiatti, R., Shimizu, N., Weis, D., Mattielli, N., 1994. Cogenetic silicarich and carbonate-rich melts trapped in mantle minerals in Kerguelen ultramafic xenoliths: implications for metasomatism in the oceanic upper mantle. Earth Planet. Sci. Lett. 123, 167-178.

Schmidt, M.W., Weidendorfer, D., 2018. Carbonatites in oceanic hot spots. Geology 46, 435-438.

Sen, G., Frey, F.A., Shimizu, N., Leeman, W.P., 1993. Evolution of the lithosphere beneath Oahu, Hawaii: rare earth element abundances in mantle xenoliths. Earth Planet. Sci. Lett. 119, 53-69.

Sen, G., Keshav, S., Bizimis, M., 2005. Hawaiian mantle xenoliths and magmas: composition and thermal character of the lithosphere. Am. Mineral. 90, 871-887. https://doi.org/10.2138/am.2005.1731.

Sen, I.S., Bizimis, M., Sen, G., Huang, S., 2011. A radiogenic Os component in the oceanic lithosphere? Constraints from Hawaiian pyroxenite xenoliths. Geochim. Cosmochim. Acta 75, 4899-4916.

Shaw, D.M., 1970. Trace element fractionation during anatexis. Geochim. Cosmochim. Acta 34, 237-243.

Sherrod, D.R., Nishimitsu, Y., Tagami, T., 2003. New K-Ar ages and the geologic evidence against rejuvenated-stage volcanism at Haleakalā, East Maui, a postshield-stage volcano of the Hawaiian island chain. GSA Bull. 115 (6), 683-694. https://doi.org/ 10.1130/0016-7606(2003)115<0683:NKAATG > 2.0.CO;2.

Silva, L.C., Le Bas, M.J., Robertson, A.H.F., 1981. An oceanic carbonatite volcano on Santiago, Cape Verde Islands. Nature 294, 644-645.

Skulski, T., Minarik, W., Watson, E.B., 1994. High-pressure experimental trace-element partitioning between Cpx and basaltic melts. Chem. Geol. 117, 127-147.

Sobolev, A.V., Nikogosian, I.K., 1994. Petrology of long-lived mantle plume magmatism: Hawaii, Pacific and Reunion Island, Indian Ocean. Petrology 2, 111-144.

Sobolev, A.V., Hofmann, A.W., Sobolev, S.V., Nikogosian, I.K., 2005. An Ol-free mantle source of Hawaiian shield basalts. Nature 434, 590-597.

Sobolev, A.V., Hofmann, A.W., Kuzmin, D.V., Yaxley, G.M., Arndt, N.T., Chung, S.-L., Danyushevsky, L.V., Elliott, T., Frey, F.A., Garcia, M.O., Gurenko, A.A., Kamenetsky, V.S., Kerr, A.C., Krivolutskaya, N.A., Matvienkov, V.V., Nikogosian, I. K., Rocholl, A., Sigurdsson, I.A., Sushchevskaya, N.M., Teklay, M., 2007. The amount of recycled crust in sources of mantle-derived melts. Science 316, 412-417.

Stille, P., Unruh, D.M., Tatsumoto, M., 1983. Pb, Sr, Nd and Hf isotopic evidence of multiple sources for Oahu, Hawaii basalts. Nature 304, 25-29.
Sun, S.-S., McDonough, F.M., 1989. Chemical and isotopic systematics of oceanic basalts: implications for mantle compositions and processes. In: Saunders, A.D., Norry, M.J. (Eds.), Magmatism in Ocean Basin, 42. Geol. Soc. Spec. Publ, pp. 313-345.

Sweeney, R.J., 1994. Carbonatite melt composition in the Earth's mantle. Earth Planet. Sci. Lett. 128, 259-270.

Sweeney, R.J., Prozetsky, V., Przybylowicz, W., 1995. Selected trace and minor element partitioning between peridotite minerals and carbonatite melts at $18-46 \mathrm{~kb}$ pressure. Geochim. Cosmochim. Acta 59, 3671-3683.

Takahashi, E., 1986. Melting of a dry peridotite KLB-1 up to $14 \mathrm{Gpa}$; implications on the origin of peridotitic upper mantle. J. Geophys. Res. 91, 9367-9382.

Tayoda, K., Horiuchi, H., Tokonami, M., 1994. Dupal anomaly of Brazilian carbonatites: geochemical correlations with hotspot in the South Atlantic and implicatons for the mantle source. Earth Planet. Sci. Lett. 126, 315-331.

Thomson, A.R., Walter, M.J., Kohn, S.C., Brooker, R.A., 2016. Slab melting as a barrier to deep carbon subduction. Nature 529, 76-79.

Trull, T., Nadeau, S., Pineau, F., Polvé, M., Javoy, M., 1993. C-He systematics in for mantle carbon hotspot xenoliths: implications contents and carbon recycling. Earth Planet. Sci. Lett. 118, 43-64.

Tucker, J.M., Hauri, E.H., Pietruszka, A.J., Garcia, M.O., Marske, J.P., Trusdell, F.A 2019. A high carbon content of the Hawaiian mantle from olivine-hosted melt inclusions. Geochim. Cosmochim. Acta 254, 156-172. https://doi.org/10.1016/j. gca.2019.04.001.

Walter, M.J., Bulanova, G.P., Armstrong, L.S., Keshav, S., Blundy, J.D., Gudfinnsson, G., Lord, O.T., Lennie, A.R., Clark, S.M., Smith, C.B., Gobbo, L., 2008. Primary carbonatite melt from deeply subducted oceanic crust. Nature 454, 622-626.

Watson, E.B., Ben, Othman D., Luck, J.-M., Hofmann, A.W., 1987. Partitioning of U, Pb, $\mathrm{Cs}, \mathrm{Yb}, \mathrm{Hf}, \mathrm{Re}$ and Os between chromian diopsidic pyroxene and haplobasaltic liquid. Chem. Geol. 62, 191-208.

Weyer, S., Münker, C., Rehkämper, M., Mezger, K., 2002. Determination of ultra-low Nb, $\mathrm{Ta}, \mathrm{Zr}$ and $\mathrm{Hf}$ concentrations and the chondritic $\mathrm{Zr} / \mathrm{Hf}$ and $\mathrm{Nb} / \mathrm{Ta}$ ratios by isotope dilution analyses with multiple collector ICP-MS. Chem. Geol. 187, 295-313.

Wirth, R., Rocholl, A., 2003. Nanocrystalline diamond from the Earth's mantle underneath Hawaii. Earth Planet. Sci. Lett. 211, 357-369.

Woolley, A.R., Barr, M.W.C., Din, V.K., Jones, G.C., Wall, F., Williams, C.T., 1991 Extrusive Carbonatites from the Uyaynah Area, United Arab Emirates. J. Petrol. 32, 1143-1167.

Yang, H.-J., Sen, G., Shimizu, N., 1998a. Mid-ocean ridge melting: Constraints from lithospheric xenoliths at Oahu, Hawaii. J. Petrol. 39, 227-295.

Yang, H.-J., Frey, F.A., Weis, D., Giret, A., Pyle, D., Michon, G., 1998b. Petrogenesis of the flood basalts forming the northern Kerguelen Archipelago: implications for the Kerguelen plume. J. Petrol. 39, 711-748.

Yang, H.-J., Frey, F.A., Clague, D.A., 2003. Constraints on the source component of the lavas forming the Hawaiian North Arch and Honolulu Volcanics. J. Petrol. 44, 603-627.

Yaxley, G.M., Crawford, A.J., Green, D.H., 1991. Evidence for carbonatite metasomatism in Spl peridotite xenoliths from western Victoria, Australia. Earth Planet. Sci. Lett. 107, 305-317.

Zou, H., Reid, M.R., 2001. Quantitative modeling of trace element fractionation during incongruent dynamic melting. Geochim. Cosmochim. Acta 65, 153-162. 